\title{
The impact of redesigning care processes on quality of care: a systematic review
}

\author{
Janneke E. van Leijen-Zeelenberg ${ }^{1 *}$, Arianne M. J. Elissen', Kerstin Grube², Arno J. A. van Raak, \\ Hubertus J. M. Vrijhoef ${ }^{3,4,5}$, Bernd Kremer ${ }^{6}$ and Dirk Ruwaard ${ }^{1}$
}

\begin{abstract}
Background: This literature review evaluates the current state of knowledge about the impact of process redesign on the quality of healthcare.

Methods: Pubmed, CINAHL, Web of Science and Business Premier Source were searched for relevant studies published in the last ten years [2004-2014]. To be included, studies had to be original research, published in English with a before-and-after study design, and be focused on changes in healthcare processes and quality of care. Studies that met the inclusion criteria were independently assessed for excellence in reporting by three reviewers using the SQUIRE checklist. Data was extracted using a framework developed for this review.

Results: Reporting adequacy varied across the studies. Process redesign interventions were diverse, and none of the studies described their effects on all dimensions of quality defined by the Institute of Medicine.

Conclusions: The results of this systematic literature review suggests that process redesign interventions have positive effects on certain aspects of quality. However, the full impact cannot be determined on the basis of the literature. A wide range of outcome measures were used, and research methods were limited. This review demonstrates the need for further investigation of the impact of redesign interventions on the quality of healthcare.
\end{abstract}

Keywords: Process redesign, Quality of care, Healthcare processes, Systematic review

\section{Background}

Growing expenditure on healthcare and ongoing efforts to improve services give impetus to change in processes and systems [1]. As life expectancy increases, so does chronic disease, which is associated with a greater demand for multidisciplinary care $[2,3]$. At the same time, public outlay on healthcare has decreased, inducing potential shortages of healthcare providers [3]. Long-term implications for the quality of care are unclear and should be carefully monitored [3]. According to the Institute of Medicine (IoM), patients do not always receive the most suitable care, at the best time or the best place [2]. Its influential report 'Crossing the Quality Chasm: A New Health System for the $21^{\text {st }}$ Century' emphasized the need to redesign healthcare processes and systems in response to this quality gap. It

\footnotetext{
* Correspondence: j.vanleijen@maastrichtuniversity.nl

${ }^{1}$ Department of Health Services Research, School for Public Health and

Primary Care (CAPHRI), Maastricht University, Maastricht, The Netherlands

Full list of author information is available at the end of the article
}

called upon providers to ensure more efficient, safe, timely, effective, patient-centered and equitable care $[2,4]$.

Although some initiatives were undertaken before 2001, the publication of the IoM report served as a catalyst [2, 5]. Numerous interventions - disease management programs for the chronically ill, quality improvement collaboratives, and change programs are tested and implemented annually on different scales and within different settings [5]. Nonetheless, progress is slow; evaluations of initiatives are inconsistent and available knowledge fragmented [5]. The effects are not homogeneous and the research designs used to measure them are generally weak $[4,6,7]$.

This study seeks to establish, through a review of the literature, what is known about the influence of redesigning healthcare processes on the quality of care delivered in the last ten years. Its specific aims are to report (a) the content of the interventions (their objectives and implementation methods); (b) the characteristics of the redesign 
investigations (study design and setting); and (c) the outcomes on quality of care (patient safety, effectiveness, efficiency, patient-centeredness, timeliness, and equitability). The objective of this literature review is to summarize the current state of knowledge on redesigning healthcare processes and present an overview of improvement efforts in the field.

The review applies several key concepts. The first is 'process redesign', defined as any methodology that focuses on creating new processes or changing existing ones in major ways [8]. That definition is deliberately broad so as to cover as many interventions as possible; recourse to dedicated design concepts - such as 'lean thinking, 'business process re-engineering' or 'six sigma' - might exclude relevant studies. The second is 'quality of care', connoting healthcare that is safe, effective, patient-centered, timely, efficient and equitable [2]. The third is 'healthcare processes', defined as "the activities that constitute healthcare including diagnosis, treatment, rehabilitation, prevention, and patient education - usually carried out by professional personnel, but also including other contributions to care, particularly by patients and their families"([9], p. 46).

\section{Methods}

\section{Information sources and search strategy}

The search strategy was guided by the PRISMA statement [10]. It was designed to access published work and comprised two stages:

1. An extensive search in Pubmed, CINAHL, Business Source Premier and Web of Science, using predefined search terms and free-text words;

2. A search of the reference lists in the included full-text articles.

From March 2014 through April 2014, the databases PubMed, CINAHL, Web of Science and Business Premier Source (EBSCO-host) were searched by one reviewer
(JvL). In PubMed, MeSH terms were used; CINAHL Heading terms were used for CINAHL; and Thesaurus terms were used for Business Premier Source. For Web of Science no predefined keywords were available. Additionally, free-text words were used for all databases. An overview of the search terms is given in Appendix 1.

The database search was limited to articles published in English between January 2004 and April 2014. Articles were included if they presented original research on redesign of healthcare processes, quality of care, and if they assessed the same outcome measures before and after an intervention. (See Table 1 for inclusion and exclusion criteria). Three reviewers (JvL, KG \& AE) independently screened titles and abstracts for relevance. The reviewers then held a consensus meeting on the inclusion of articles. When that did not yield agreement, the full text was reviewed and discussed to arrive at a decision. Subsequently, reference lists and bibliographies of all included full-text articles from the first stage were searched for additional studies.

\section{Critical appraisal}

Studies meeting the criteria were assessed independently for reporting excellence by three reviewers (JvL, AE \& $K G)$, prior to inclusion in light of the Standards for Quality Improvement Reporting Excellence (SQUIRE). That checklist provides guidelines for reporting of studies assessing the effectiveness of interventions to improve quality and safety of care. Its 19 items comprise 38 components [11]. Any disagreements between reviewers were resolved through consensus.

\section{Data extraction and analysis}

After compliance with the reporting guidelines had been assessed, data were extracted independently by three reviewers (JvL, KG \& AE) from the results and discussion/ conclusion sections. For that purpose, a form was developed. The form contained variables such as publication

Table 1 Inclusion and exclusion criteria

\begin{tabular}{l} 
Inclusion criteria \\
\hline Participants: organizations with a primary focus on healthcare provision \\
Intervention: either changes in or redesigns of processes in healthcare organizations \\
or healthcare innovations with a clearly described objective to improve quality of \\
care \\
Outcome measures: quality of care, changeability, process efficiency, patient \\
satisfaction, employee satisfaction, costs of care, facilitators or barriers to \\
implementation, equity, timeliness of care, patient safety, effectiveness. \\
Outcome measures should be clearly described and be consistent before and after \\
intervention \\
Types of studies: RCTs, controlled before-and-after studies, before-and-after studies, \\
interrupted time series, case studies (if using before-and-after measures), mixed \\
methods studies (if using before-and-after measures), observational studies (if using \\
before-and-after measures)
\end{tabular}

Exclusion criteria

Articles published before 2003

Articles in which the intervention, data collection methods, data analysis or research context is not described

Articles published in languages other than English.

\author{
Articles without abstract, articles without before-and-after \\ measurement
}

Editorials, viewpoints, non-articles, interviews 
year, study objectives, characteristics of the redesign and outcome measures. Any disagreements were resolved through consensus. Meta-analysis could not be performed because the studies used different outcome measures and research designs.

\section{Results}

Figure 1 shows the steps leading to inclusion in the review. Initially, after removing duplicates $(\mathrm{N}=27), 451$ articles were found in the first stage, 11 of which were then included on the basis of their titles and abstracts. Perusal of their reference lists yielded another 24 articles for screening of title and abstract. Based on titles and abstracts, 21 articles were assessed for eligibility. On eight of these, consensus was only reached after reviewing the full text. After assessing the reporting excellence, three articles were excluded. One was removed because it did not describe data collection and timepoints, so it could not be determined whether a before-and-after measurement was performed. Another was removed because it was unclear whether it concerned original research; moreover, the main intervention (presence of a nurse coordinator) did not qualify as process redesign. The third was removed because it was unclear whether the intervention was actually implemented and whether before-and-after measurement was carried out but also because the outcome measures differed at various timepoints. In total, 18 articles were included in the final review.

\section{Reporting excellence}

Table 2 summarizes the findings according to SQUIRE guidelines. The number of components described range from 11 [12] to 27 [13], with most articles reporting on 20 or more [13-22]. Overall, methods of evaluation and analysis are the least well described. The majority described the research setting $(\mathrm{N}=16)$ [12-27], intervention components and parts $(\mathrm{N}=16)$ [13-16, 18-28], main factors in the choice of intervention $(\mathrm{N}=15)$ [11, 13-18, 20, 22-28], and primary and secondary outcomes $(\mathrm{N}=15)$ [12-14, 16-24, 28, 29]. Thirteen articles presented evidence on the strength of the association between the intervention and changes observed $(\mathrm{N}=13)$ $[12,13,16-22,24,25,27-29]$. Half gave details on the qualitative and quantitative methods applied $(\mathrm{N}=9)$ [13, $17-20,24,25,28,29]$ or aligned the unit of analysis with the intervention $(N=9)$ [13-15, 18-21, 24, 28]. Six described internal and external validity [13, 15, 17-20, 28], whereas two dealt with the validity and reliability of instruments [17, 28]. Whereas none of the articles explicitly stated the study questions, all of them specified the aims of the intervention. Most data concerned changes observed in the care delivery process $(\mathrm{N}=12)$

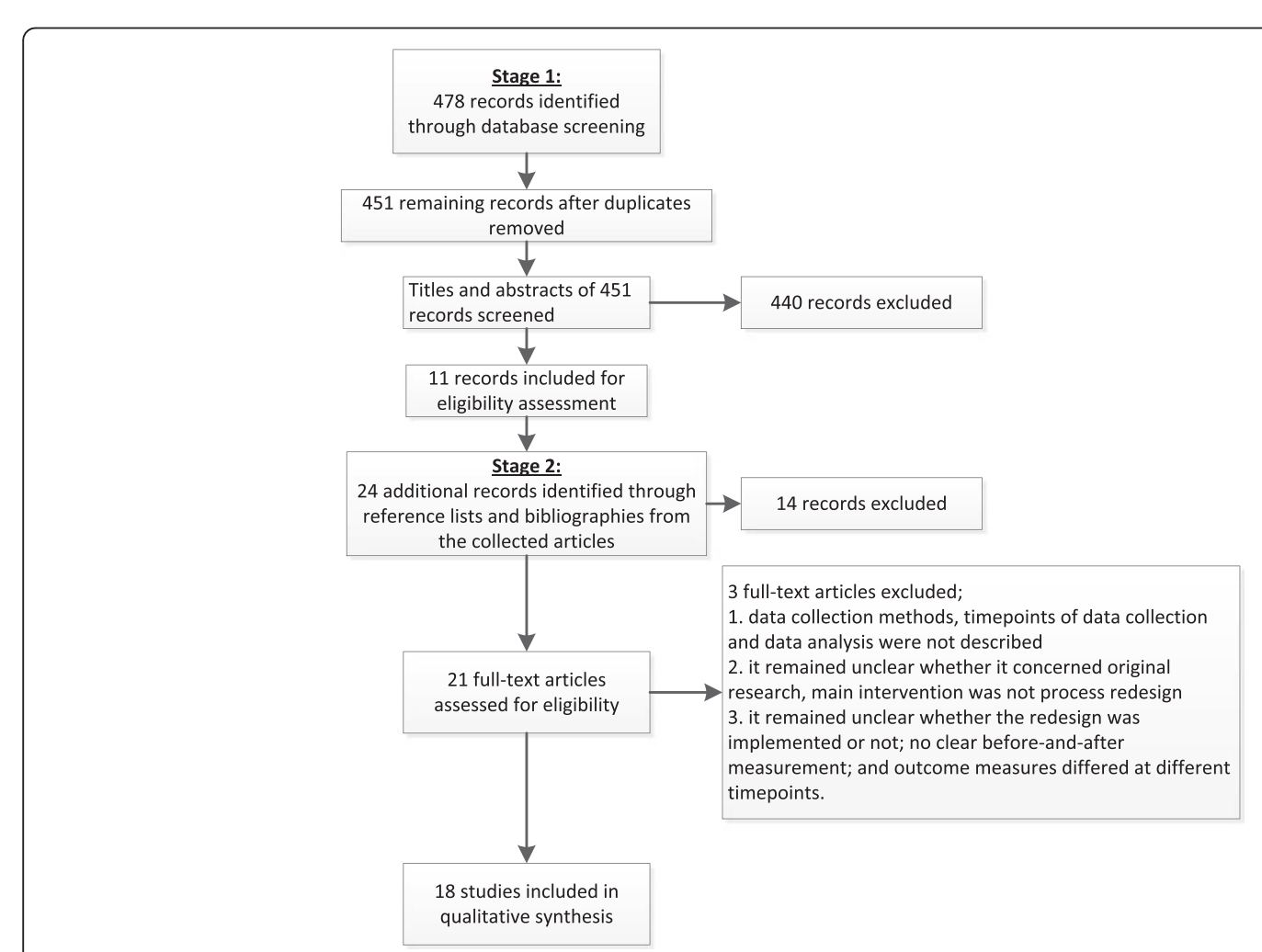

Fig. 1 Search strategy 
Table 2 Overview of reporting excellence according to the SQUIRE guidelines

\begin{tabular}{|c|c|c|c|c|c|c|c|c|}
\hline \multirow[t]{2}{*}{ Reference } & \multirow[t]{2}{*}{ Introduction } & \multicolumn{3}{|l|}{ Methods } & \multicolumn{2}{|l|}{ Results } & \multirow{2}{*}{$\begin{array}{l}\text { Conclusion \& } \\
\text { discussion }\end{array}$} & \multirow{2}{*}{$\begin{array}{l}\text { Total \# } \\
\text { SQUIRE } \\
\text { components } \\
\text { mentioned }\end{array}$} \\
\hline & & Intervention & $\begin{array}{l}\text { Methods of } \\
\text { evaluation }\end{array}$ & Analysis & Setting & Changes in process & & \\
\hline $\begin{array}{l}1 . \\
\text { Pennell, } \\
\text { et al. } \\
(2005)\end{array}$ & $\begin{array}{l}\text { Describes } 4 / 5 \\
\text { components } \\
\text { (background } \\
\text { knowledge; } \\
\text { local problem; } \\
\text { intended aim; } \\
\text { and who, } \\
\text { what and why } \\
\text { of } \\
\text { intervention) }\end{array}$ & $\begin{array}{l}\text { Describes } 3 / 10 \\
\text { components (indicated } \\
\text { main factors } \\
\text { contributing to choice of } \\
\text { intervention; study design } \\
\text { for measuring } \\
\text { its impact; explains } \\
\text { how method was applied) }\end{array}$ & $\begin{array}{l}\text { Describes } 2 / 5 \\
\text { components } \\
\text { (instruments to } \\
\text { measure } \\
\text { effectiveness of } \\
\text { implementation, } \\
\text { primary and } \\
\text { secondary } \\
\text { outcomes) }\end{array}$ & $\begin{array}{l}\text { Describes } 1 / 4 \\
\text { components } \\
\text { (details } \\
\text { of qualitative and } \\
\text { quantitative } \\
\text { methods) }\end{array}$ & $\begin{array}{l}\text { Describes } 2 / 4 \text { components } \\
\text { (documents degree of } \\
\text { success in implementation; } \\
\text { describes how and why the } \\
\text { initial plan evolved) }\end{array}$ & $\begin{array}{l}\text { Describes } 4 / 5 \text { components } \\
\text { (presents data on changes } \\
\text { observed in the care } \\
\text { delivery process; presents } \\
\text { data on changes observed } \\
\text { in measures of patient } \\
\text { outcome; considers } \\
\text { benefits, harms, } \\
\text { unexpected results, } \\
\text { problems, failures;presents } \\
\text { evidence regarding } \\
\text { strength of association } \\
\text { between intervention and } \\
\text { changes) }\end{array}$ & $\begin{array}{l}\text { Describes } 3 / 5 \\
\text { components } \\
\text { (summary, } \\
\text { interpretations, } \\
\text { conclusions) }\end{array}$ & $19 / 38$ \\
\hline $\begin{array}{l}2 . \\
\text { King, Ben- } \\
\text { Tovim, Bas- } \\
\text { sham } \\
(2006)\end{array}$ & $\begin{array}{l}\text { Describes } 3 / 5 \\
\text { components } \\
\text { (local } \\
\text { problem; } \\
\text { intended aim; } \\
\text { and who, } \\
\text { what and why } \\
\text { of } \\
\text { intervention) }\end{array}$ & $\begin{array}{l}\text { Describes } 4 / 10 \\
\text { components (setting, } \\
\text { intervention and } \\
\text { components /parts; } \\
\text { indicated main factors } \\
\text { contributing to choice of } \\
\text { intervention, } \\
\text { implementation plan) }\end{array}$ & $\begin{array}{l}\text { Describes } 1 / 5 \\
\text { components } \\
\text { (primary and } \\
\text { secondary } \\
\text { outcomes) }\end{array}$ & $\begin{array}{l}\text { Describes } 2 / 4 \\
\text { components } \\
\text { (details } \\
\text { of qualitative and } \\
\text { quantitative } \\
\text { methods;aligns } \\
\text { unit } \\
\text { of analysis with } \\
\text { the intervention) }\end{array}$ & $\begin{array}{l}\text { Describes } 3 / 4 \text { components } \\
\text { (relevant elements of setting } \\
\text { or settings; explains the } \\
\text { actual course of the } \\
\text { intervention; describes how } \\
\text { and why the initial plan } \\
\text { evolved) }\end{array}$ & $\begin{array}{l}\text { Describes } 3 / 5 \text { components } \\
\text { (presents data on changes } \\
\text { observed in the care } \\
\text { delivery process; presents } \\
\text { data on changes observed } \\
\text { in measures of patient } \\
\text { outcome; presents } \\
\text { evidence on strength of } \\
\text { association between } \\
\text { intervention and changes) }\end{array}$ & $\begin{array}{l}\text { Describes } 3 / 5 \\
\text { components } \\
\text { (summary; } \\
\text { limitations; } \\
\text { conclusions) }\end{array}$ & $19 / 38$ \\
\hline $\begin{array}{l}3 . \\
\text { Raab, } \\
\text { Andrew- } \\
\text { JaJa, Con- } \\
\text { del, } \\
\text { et al.(2006) }\end{array}$ & $\begin{array}{l}\text { Describes } 3 / 5 \\
\text { components } \\
\text { (background } \\
\text { knowledge; } \\
\text { intended aim; } \\
\text { and who, } \\
\text { what and why } \\
\text { of } \\
\text { intervention) }\end{array}$ & $\begin{array}{l}\text { Describes } 5 / 10 \\
\text { components (setting; } \\
\text { intervention and } \\
\text { components/ parts; } \\
\text { indicated main factors } \\
\text { contributing to choice of } \\
\text { intervention; study design } \\
\text { for measuring impact } \\
\text { intervention; explains how } \\
\text { method was applied) }\end{array}$ & $\begin{array}{l}\text { Describes } 1 / 5 \\
\text { components } \\
\text { (methods used to } \\
\text { assure data quality } \\
\text { and adequacy) }\end{array}$ & $\begin{array}{l}\text { Describes } 3 / 4 \\
\text { components } \\
\text { (details } \\
\text { of qualitative and } \\
\text { quantitative } \\
\text { methods; specifies } \\
\text { degree of } \\
\text { expected } \\
\text { variability; } \\
\text { describes analytic } \\
\text { method } \\
\text { used to } \\
\text { demonstrate } \\
\text { effects of time) }\end{array}$ & $\begin{array}{l}\text { Describes } 2 / 4 \text { components } \\
\text { (explains the actual course } \\
\text { of the intervention; } \\
\text { documents degree of } \\
\text { success in implementation) }\end{array}$ & $\begin{array}{l}\text { Describes } 2 / 5 \text { components } \\
\text { (considers benefits, harms, } \\
\text { unexpected results, } \\
\text { problems, failures; presents } \\
\text { evidence regarding } \\
\text { strength of association } \\
\text { between intervention and } \\
\text { changes) }\end{array}$ & $\begin{array}{l}\text { Describes } 3 / 5 \\
\text { components } \\
\text { (relation to } \\
\text { other evidence, } \\
\text { limitations, } \\
\text { interpretations) }\end{array}$ & $19 / 38$ \\
\hline $\begin{array}{l}4 . \\
\text { Raab, et al. } \\
\text { (2006) }\end{array}$ & $\begin{array}{l}\text { Describes 3/5 } \\
\text { components } \\
\text { (background } \\
\text { knowledge; } \\
\text { intended aim; }\end{array}$ & $\begin{array}{l}\text { Describes } 6 / 10 \\
\text { components (setting; } \\
\text { intervention and } \\
\text { components/ parts; } \\
\text { indicated main factors }\end{array}$ & $\begin{array}{l}\text { Describes 0/5 } \\
\text { components }\end{array}$ & $\begin{array}{l}\text { Describes } 1 / 4 \\
\text { components } \\
\text { (describes analytic } \\
\text { method used to }\end{array}$ & Describes $0 / 4$ components & $\begin{array}{l}\text { Describes } 1 / 5 \text { components } \\
\text { (presents evidence } \\
\text { regarding strength of } \\
\text { association between }\end{array}$ & $\begin{array}{l}\text { Describes } 4 / 5 \\
\text { components } \\
\text { (relation to } \\
\text { other evidence; } \\
\text { limitations; }\end{array}$ & $15 / 38$ \\
\hline
\end{tabular}


Table 2 Overview of reporting excellence according to the SQUIRE guidelines (Continued)

\begin{tabular}{|c|c|c|c|c|c|c|c|c|}
\hline & $\begin{array}{l}\text { and who, } \\
\text { what and why } \\
\text { of } \\
\text { intervention) }\end{array}$ & $\begin{array}{l}\text { contributing to choice } \\
\text { of intervention; } \\
\text { expected change } \\
\text { mechanisms; study } \\
\text { design for measuring } \\
\text { impact intervention; } \\
\text { explains how method } \\
\text { was applied) }\end{array}$ & & $\begin{array}{l}\text { demonstrate } \\
\text { effects of time) }\end{array}$ & & $\begin{array}{l}\text { intervention } \\
\text { and changes) }\end{array}$ & $\begin{array}{l}\text { interpretations; } \\
\text { conclusions) }\end{array}$ & \\
\hline $\begin{array}{l}5 . \\
\text { Shannon, } \\
\text { et al. } \\
(2006)\end{array}$ & $\begin{array}{l}\text { Describes } 3 / 5 \\
\text { components } \\
\text { (background } \\
\text { knowledge; } \\
\text { intended aim; } \\
\text { and who, } \\
\text { what and why } \\
\text { of } \\
\text { intervention) }\end{array}$ & $\begin{array}{l}\text { Describes } 4 / 10 \\
\text { components (ethical } \\
\text { issues; setting; } \\
\text { intervention and } \\
\text { components/ parts; } \\
\text { Implementation plan) }\end{array}$ & $\begin{array}{l}\text { Describes } 1 / 5 \\
\text { components } \\
\text { (primary and } \\
\text { secondary } \\
\text { outcomes) }\end{array}$ & $\begin{array}{l}\text { Describes } 2 / 4 \\
\text { components } \\
\text { (aligns unit of } \\
\text { analysis with the } \\
\text { intervention; } \\
\text { describes analytic } \\
\text { method used to } \\
\text { demonstrate } \\
\text { effects } \\
\text { of time) }\end{array}$ & $\begin{array}{l}\text { Describes } 2 / 4 \text { components } \\
\text { (explains the actual course } \\
\text { of the intervention; } \\
\text { documents degree of } \\
\text { success in implementation) }\end{array}$ & $\begin{array}{l}\text { Describes } 4 / 5 \text { components } \\
\text { (presents data on changes } \\
\text { observed in the care } \\
\text { delivery } \\
\text { process;presents data } \\
\text { on changes observed } \\
\text { in measures of patient } \\
\text { outcome;considers } \\
\text { benefits, harms, } \\
\text { unexpected results, } \\
\text { problems, failures; presents } \\
\text { evidence regarding } \\
\text { strength of association } \\
\text { between intervention and } \\
\text { changes) }\end{array}$ & $\begin{array}{l}\text { Describes } 4 / 5 \\
\text { components } \\
\text { (summary; } \\
\text { relation to } \\
\text { other evidence; } \\
\text { limitations; } \\
\text { interpretations) }\end{array}$ & $20 / 38$ \\
\hline $\begin{array}{l}6 . \\
\text { Kelly, } \\
\text { Bryant, Cox } \\
\text { et al. } \\
\text { (2007) }\end{array}$ & $\begin{array}{l}\text { Describes } 4 / 5 \\
\text { components } \\
\text { (background } \\
\text { knowledge; } \\
\text { local problem; } \\
\text { intended aim; } \\
\text { and who, } \\
\text { what and why } \\
\text { of } \\
\text { intervention) }\end{array}$ & $\begin{array}{l}\text { Describes 5/10 } \\
\text { components (setting; } \\
\text { intervention and } \\
\text { components/parts; } \\
\text { implementation plan; } \\
\text { study design for } \\
\text { measuring impact } \\
\text { intervention; explains } \\
\text { how method was } \\
\text { applied) }\end{array}$ & $\begin{array}{l}\text { Describes } 3 / 5 \\
\text { components } \\
\text { (instruments to } \\
\text { measure } \\
\text { effectiveness of } \\
\text { implementation; } \\
\text { contribution of } \\
\text { components of } \\
\text { intervention to } \\
\text { effectiveness; } \\
\text { primary and } \\
\text { secondary } \\
\text { outcomes) }\end{array}$ & $\begin{array}{l}\text { Describes } 1 / 4 \\
\text { components } \\
\text { (aligns unit of } \\
\text { analysis with the } \\
\text { intervention) }\end{array}$ & $\begin{array}{l}\text { Describes } 2 / 4 \text { components } \\
\text { (explains the actual course } \\
\text { of the } \\
\text { intervention;documents } \\
\text { degree of success in } \\
\text { implementation) }\end{array}$ & $\begin{array}{l}\text { Describes } 2 / 5 \text { components } \\
\text { (presents data on changes } \\
\text { observed in care delivery } \\
\text { process; includes summary } \\
\text { of missing data) }\end{array}$ & $\begin{array}{l}\text { Describes } 5 / 5 \\
\text { components } \\
\text { (summary; } \\
\text { relation to } \\
\text { other evidence; } \\
\text { limitations; } \\
\text { interpretations; } \\
\text { conclusions) }\end{array}$ & $22 / 38$ \\
\hline $\begin{array}{l}7 . \\
\text { Kim, et al. } \\
\text { (2007) }\end{array}$ & $\begin{array}{l}\text { Describes } 4 / 5 \\
\text { components } \\
\text { (background } \\
\text { knowledge; } \\
\text { local problem; } \\
\text { intended aim; } \\
\text { and who, } \\
\text { what and why } \\
\text { of } \\
\text { intervention) }\end{array}$ & $\begin{array}{l}\text { Describes } 5 / 10 \\
\text { components (ethical } \\
\text { issues; setting; } \\
\text { intervention and } \\
\text { components/ parts; } \\
\text { indicated main factors } \\
\text { contributing to choice } \\
\text { of intervention; study } \\
\text { design for measuring } \\
\text { impact intervention; }\end{array}$ & $\begin{array}{l}\text { Describes } 2 / 5 \\
\text { components } \\
\text { (instruments to } \\
\text { measure } \\
\text { effectiveness of } \\
\text { implementation; } \\
\text { contribution of } \\
\text { components of } \\
\text { intervention to } \\
\text { effectiveness) }\end{array}$ & $\begin{array}{l}\text { Describes } 1 / 4 \\
\text { components } \\
\text { (aligns unit of } \\
\text { analysis with the } \\
\text { intervention) }\end{array}$ & $\begin{array}{l}\text { Describes } 2 / 4 \text { components } \\
\text { (explains the actual course } \\
\text { of the intervention; } \\
\text { documents degree of } \\
\text { success in implementation) }\end{array}$ & $\begin{array}{l}\text { Describes } 2 / 5 \text { components } \\
\text { (presents data on changes } \\
\text { observed in care delivery } \\
\text { process; includes summary } \\
\text { of missing data) }\end{array}$ & $\begin{array}{l}\text { Describes } 4 / 5 \\
\text { components } \\
\text { (summary; } \\
\text { relation to } \\
\text { other evidence; } \\
\text { limitations; } \\
\text { interpretations) }\end{array}$ & $20 / 38$ \\
\hline
\end{tabular}
of the

tion;documents

degree of success

interpretations; 
Table 2 Overview of reporting excellence according to the SQUIRE guidelines (Continued)

\begin{tabular}{|c|c|c|}
\hline $\begin{array}{l}9 . \\
\text { Shendell- } \\
\text { Falik, } \\
\text { Feinson, } \\
\text { Mohr } \\
(2007)\end{array}$ & $\begin{array}{l}\text { Describes } 4 / 5 \\
\text { components } \\
\text { (background } \\
\text { knowledge; } \\
\text { local problem; } \\
\text { intended aim; } \\
\text { and who, } \\
\text { what and why } \\
\text { of } \\
\text { intervention) }\end{array}$ & $\begin{array}{l}\text { Describes } 4 / 10 \\
\text { components (setting; } \\
\text { intervention; } \\
\text { components/parts; } \\
\text { indicated main factors } \\
\text { contributing to choice } \\
\text { of intervention; } \\
\text { expected change } \\
\text { mechanisms) }\end{array}$ \\
\hline $\begin{array}{l}10 . \\
\text { Wood, } \\
\text { Brennan, } \\
\text { Chaudhry, } \\
\text { et al. } \\
\text { (2008) }\end{array}$ & $\begin{array}{l}\text { Describes } 3 / 5 \\
\text { components } \\
\text { (background } \\
\text { knowledge; } \\
\text { intended aim; } \\
\text { and who, } \\
\text { what and why } \\
\text { of } \\
\text { intervention) }\end{array}$ & $\begin{array}{l}\text { Describes } 2 / 10 \\
\text { components (setting; } \\
\text { intervention and } \\
\text { components/parts) }\end{array}$ \\
\hline $\begin{array}{l}11 . \\
\text { Reid, et al. } \\
\text { (2009) }\end{array}$ & $\begin{array}{l}\text { Describes } 4 / 5 \\
\text { components } \\
\text { (background } \\
\text { knowledge; local } \\
\text { problem; intended } \\
\text { aim; and who, } \\
\text { what and why } \\
\text { of } \\
\text { intervention) }\end{array}$ & $\begin{array}{l}\text { Describes } 7 / 10 \\
\text { components (ethical } \\
\text { issues; setting; } \\
\text { intervention and } \\
\text { components/parts; } \\
\text { indicated main factors } \\
\text { contributing to choice } \\
\text { of intervention; study } \\
\text { design for measuring } \\
\text { impact of intervention; } \\
\text { explains how method }\end{array}$ \\
\hline
\end{tabular}

explains how method

was applied; internal

and external validity)

Describes 3/5

Raab, components

Grzybicki, (background

Condel, knowledge;

(2007) and who,

what and why

of

intervention)

Describes 6/10

components (setting:

intervention and

components/parts;

indicated main factors

of intervention;

implementation plan;

study design for

measuring impact

intervention; explains

how method was

applied)

\section{Describes 3/5 Describes 0/4

components components \\ components}

(instruments to

measure

effectiveness of

implementation;

contribution of

components of

intervention to

effectiveness;

primary and

secondary

outcomes)

Describes 1/5

components

primary and

secondary

outcomes)

Describes 3/5

components

(instruments to

measure

effectiveness of

implementation;

primary and

secondary outcomes;

methods used to

assure data quality

and adequacy) components

(describes analytic

demonstrate

f time)

Describes $4 / 4$

components (relevant

elements of setting or

settings; explains the

actual course of the

intervention; documents

degree of success in

implementation;describes

how and why the initial

plan evolved)

Describes 0/4

components

Describes $1 / 4$

components (actual

course of the

intervention)

Describes 3/4

components

(details of

qualitative and

quantitative

methods; aligns

unit of analysis

with the

intervention;

method used to

\section{Describes 0/4}

components
Describes 2/5

Describes $3 / 5$

components

(summary;

interpretations)

delivery

considers benefits,

harms, unexpected

results, problems,

failures)

components (presents

delivery process;

measures of patient

evidence regarding

strength of association

between intervention

and changes)

Describes $1 / 5$

components (evidence

regarding strength of

association between

intervention and

changes)

of patient outcome;

regarding strength of interpretations;
Describes $3 / 5$

Describes 2/5

components

(summary;

observed in the care conclusions)

changes observed in

outcome; presents

Describes $3 / 5$

components

(summary;

relation to

other evidence;

conclusions)

Describes 3/5

components (presents

Describes $5 / 5$

data on changes

observed in measures

components

(summary;

other evidence;

presents evidence

limitations;

association between

conclusions)

20/38

changes: includes 
Table 2 Overview of reporting excellence according to the SQUIRE guidelines (Continued)

\begin{tabular}{|c|c|c|c|}
\hline $\begin{array}{l}13 . \\
\text { Ravikumar, } \\
\text { et al. } \\
\text { (2010) }\end{array}$ & $\begin{array}{l}\text { Describes } 3 / 5 \\
\text { components } \\
\text { (background } \\
\text { knowledge; } \\
\text { intended aim; } \\
\text { and who, } \\
\text { what and why } \\
\text { of } \\
\text { intervention) }\end{array}$ & $\begin{array}{l}\text { Describes } 7 / 10 \\
\text { components (setting; } \\
\text { intervention and } \\
\text { components/parts; } \\
\text { indicated main factors } \\
\text { contributing to choice of } \\
\text { intervention; } \\
\text { implementation plan; } \\
\text { study design for } \\
\text { measuring impact of } \\
\text { intervention; explains how } \\
\text { method was applied; } \\
\text { internal and external } \\
\text { validity) }\end{array}$ & $\begin{array}{l}\text { Describes } 1 / 5 \\
\text { components } \\
\text { (primary and } \\
\text { secondary } \\
\text { outcomes) }\end{array}$ \\
\hline $\begin{array}{l}14 . \\
\text { Hwang, } \\
\text { Lee, Shin } \\
\text { (2011) }\end{array}$ & $\begin{array}{l}\text { Describes } 4 / 5 \\
\text { components } \\
\text { (background } \\
\text { knowledge; } \\
\text { local problem; } \\
\text { intended aim; } \\
\text { and who, } \\
\text { what and why } \\
\text { of } \\
\text { intervention) }\end{array}$ & $\begin{array}{l}\text { Describes } 4 / 10 \\
\text { components, (setting; } \\
\text { intervention and } \\
\text { components parts; } \\
\text { indicated main factors } \\
\text { contributing to choice of } \\
\text { intervention; study design } \\
\text { for measuring intervention) }\end{array}$ & $\begin{array}{l}\text { Describes } 2 / 5 \\
\text { components } \\
\text { (primary and } \\
\text { secondary } \\
\text { outcomes; } \\
\text { methods used to } \\
\text { assure data quality } \\
\text { and adequacy) }\end{array}$ \\
\hline
\end{tabular}

demonstrate effects

was applied; internal

and external validity)

12. Describes $3 / 5$

Auerbach, components

et al. (background

knowledge;

and who,

what and why

of

intervention)

components (setting;

intervention and

components/parts;

contributing to choice of

intervention;

implementation plan; plan

for assessment of

implementation; study

design for measuring

mpact of intervention;

explains how method was

applied; internal and

external validity)

\begin{tabular}{|c|c|}
\hline $\begin{array}{l}\text { Describes } 2 / 5 \\
\text { components } \\
\text { (instruments to } \\
\text { measure } \\
\text { effectiveness of } \\
\text { implementation; } \\
\text { primary and } \\
\text { secondary } \\
\text { outcomes) }\end{array}$ & $\begin{array}{l}\text { Describes } 3 / 4 \\
\text { components } \\
\text { (details } \\
\text { of qualitative and } \\
\text { quantitative } \\
\text { methods; aligns } \\
\text { unit of analysis } \\
\text { with the } \\
\text { intervention; } \\
\text { describes analytic } \\
\text { method used to } \\
\text { demonstrate } \\
\text { effects } \\
\text { of time) }\end{array}$ \\
\hline
\end{tabular}

Describes 2/4

components (relevant elements of setting or

settings; documents

degree of success in implementation)

\section{Describes 3/4 Describes $4 / 4$}

components (relevant

details elements of setting or

of qualitative and settings; explains the

quantitative actual course of the

methods; aligns intervention; documents

unit of analysis degree of success in

with the implementation; describes

intervention;

how and why the initial

describes analytic plan evolved)

method used to

demonstrate

effects

of time)

Describes 0/4

Describes 0/4

components

components summary of missing

data)

Describes 5/5

Describes $4 / 5$

components

components (presents

data on changes

observed in the care

delivery process:

presents data on

changes observed in

measures of patient

outcome;considers

unexpected results,

problems,

failures;presents

evidence regarding

strength of association

between intervention

and changes; includes

Describes $3 / 5$

components (presents

data on changes

observed in measures

of patient outcome;

considers benefits,

harms, unexpected

results, problems,

failures; presents

evidence regarding

strength of association

between intervention and

changes)

Describes 3/5

components (data on

changes observed in

the care delivery

process: data on

changes observed in

measures of patient

outcome;considers

benefits, harms,

unexpected results,

problems, failures)
Describes $5 / 5$

components

relation to

other evidence;

limitations;

interpretations)

Describes 4/5

(relation to

other evidence;

limitations;

interpretations

conclusions)

relation to

other evidence:

limitations;

interpretations;

conclusions) 
Table 2 Overview of reporting excellence according to the SQUIRE guidelines (Continued)

\begin{tabular}{|c|c|c|c|c|c|c|c|c|}
\hline $\begin{array}{l}15 . \\
\text { Collar, et al. } \\
\text { (2012) }\end{array}$ & $\begin{array}{l}\text { Describes } 1 / 5 \\
\text { components } \\
\text { (intended aim) }\end{array}$ & $\begin{array}{l}\text { Describes } 6 / 10 \\
\text { components } \\
\text { (intervention and } \\
\text { components/parts; } \\
\text { indicated main factors } \\
\text { contributing to choice of } \\
\text { intervention; } \\
\text { implementation plan; } \\
\text { study design for } \\
\text { measuring impact of } \\
\text { intervention; explains how } \\
\text { method was applied; } \\
\text { internal and external } \\
\text { validity) }\end{array}$ & $\begin{array}{l}\text { Describes } 2 / 5 \\
\text { components } \\
\text { (primary and } \\
\text { secondary } \\
\text { outcomes; reports } \\
\text { validity and } \\
\text { reliability of } \\
\text { instruments) }\end{array}$ & $\begin{array}{l}\text { Describes } 2 / 4 \\
\text { components } \\
\text { (details of } \\
\text { qualitative and } \\
\text { quantitative } \\
\text { methods; aligns } \\
\text { unit of analysis } \\
\text { with the } \\
\text { intervention) }\end{array}$ & $\begin{array}{l}\text { Describes 0/5 } \\
\text { components }\end{array}$ & $\begin{array}{l}\text { Describes } 4 / 5 \\
\text { components (presents } \\
\text { data on changes } \\
\text { observed in the care } \\
\text { delivery } \\
\text { process;presents data } \\
\text { on changes observed } \\
\text { in measures of patient } \\
\text { outcome;considers } \\
\text { benefits, harms, } \\
\text { unexpected results, } \\
\text { problems, failures;presents } \\
\text { evidence regarding } \\
\text { strength of association } \\
\text { between intervention and } \\
\text { changes) }\end{array}$ & $\begin{array}{l}\text { Describes } 4 / 5 \\
\text { components } \\
\text { (relation to } \\
\text { Other evidence; } \\
\text { limitations; } \\
\text { interpretations; } \\
\text { conclusions) }\end{array}$ & \\
\hline $\begin{array}{l}16 . \\
\text { Krening, } \\
\text { Rehling- } \\
\text { Anthony, } \\
\text { Garko } \\
(2012)\end{array}$ & $\begin{array}{l}\text { Describes } 4 / 5 \\
\text { components } \\
\text { (background } \\
\text { knowledge; } \\
\text { local problem; } \\
\text { intended aim; } \\
\text { and who, } \\
\text { what and why } \\
\text { of } \\
\text { intervention) }\end{array}$ & $\begin{array}{l}\text { Describes } 5 / 10 \\
\text { components (setting; } \\
\text { intervention and } \\
\text { components/ } \\
\text { parts;indicated main } \\
\text { factors contributing to } \\
\text { choice of intervention; } \\
\text { implementation plan; } \\
\text { expected change } \\
\text { mechanisms) }\end{array}$ & $\begin{array}{l}\text { Describes } 3 / 5 \\
\text { components } \\
\text { (instruments to } \\
\text { measure } \\
\text { effectiveness of } \\
\text { implementation; } \\
\text { primary and } \\
\text { secondary } \\
\text { outcomes; explains } \\
\text { methods used to } \\
\text { assure data quality } \\
\text { and } \\
\text { adequacy) }\end{array}$ & $\begin{array}{l}\text { Describes 0/4 } \\
\text { components }\end{array}$ & $\begin{array}{l}\text { Describes } 4 / 4 \\
\text { components (relevant } \\
\text { elements of setting or } \\
\text { settings; explains the } \\
\text { actual course of the } \\
\text { intervention; documents } \\
\text { degree of success in } \\
\text { implementation; describes } \\
\text { how and why the initial } \\
\text { plan evolved) }\end{array}$ & $\begin{array}{l}\text { Describes } 4 / 5 \text { components } \\
\text { (presents data on changes } \\
\text { observed in the care } \\
\text { delivery process; presents } \\
\text { data on changes observed } \\
\text { in measures of patient } \\
\text { outcome; considers } \\
\text { benefits, harms, } \\
\text { unexpected results, } \\
\text { problems, failures; presents } \\
\text { evidence regarding } \\
\text { strength of association } \\
\text { between intervention and } \\
\text { changes) }\end{array}$ & $\begin{array}{l}\text { Describes } 4 / 5 \\
\text { components } \\
\text { summary; } \\
\text { limitations; } \\
\text { interpretations; } \\
\text { conclusions) }\end{array}$ & $20 / 38$ \\
\hline $\begin{array}{l}17 . \\
\text { Murray, } \\
\text { Christen, } \\
\text { Marsh, } \\
\text { et al.(2012) }\end{array}$ & $\begin{array}{l}\text { Describes } 4 / 5 \\
\text { components } \\
\text { (background } \\
\text { knowledge; } \\
\text { local problem; } \\
\text { intended aim; } \\
\text { and who, } \\
\text { what and why } \\
\text { of } \\
\text { intervention) }\end{array}$ & $\begin{array}{l}\text { Describes } 6 / 10 \\
\text { components (setting; } \\
\text { intervention and } \\
\text { components/parts; } \\
\text { indicated main factors } \\
\text { contributing to choice of } \\
\text { intervention; } \\
\text { implementation plan; } \\
\text { expected change } \\
\text { mechanisms; internal and } \\
\text { external validity) }\end{array}$ & $\begin{array}{l}\text { Describes } 3 / 5 \\
\text { components } \\
\text { (instruments to } \\
\text { measure } \\
\text { effectiveness of } \\
\text { implementation; } \\
\text { primary and } \\
\text { secondary } \\
\text { outcomes; } \\
\text { methods used to } \\
\text { assure data quality } \\
\text { and adequacy) }\end{array}$ & $\begin{array}{l}\text { Describes } 2 / 4 \\
\text { components } \\
\text { (details } \\
\text { of qualitative and } \\
\text { quantitative } \\
\text { methods; aligns } \\
\text { unit of analysis } \\
\text { with the } \\
\text { intervention) }\end{array}$ & $\begin{array}{l}\text { Describes } 2 / 4 \\
\text { components (relevant } \\
\text { elements of setting or } \\
\text { settings; describes how } \\
\text { and why the initial plan } \\
\text { evolved) }\end{array}$ & $\begin{array}{l}\text { Describes } 4 / 5 \text { components } \\
\text { (presents data on changes } \\
\text { observed in the care } \\
\text { delivery } \\
\text { process;presents data } \\
\text { on changes observed } \\
\text { in measures of patient } \\
\text { outcome; presents } \\
\text { evidence regarding } \\
\text { strength of association } \\
\text { between intervention and } \\
\text { changes; includes summary } \\
\text { of missing data) }\end{array}$ & $\begin{array}{l}\text { Describes 5/5 } \\
\text { components } \\
\text { (summary; } \\
\text { relation to } \\
\text { other evidence; } \\
\text { limitations; } \\
\text { interpretations; } \\
\text { conclusions) }\end{array}$ & $23 / 38$ \\
\hline $\begin{array}{l}18 . \\
\text { Liss, et al. } \\
\text { (2013) }\end{array}$ & $\begin{array}{l}\text { Describes } 4 / 5 \\
\text { components } \\
\text { (background } \\
\text { knowledge; }\end{array}$ & $\begin{array}{l}\text { Describes } 4 / 10 \\
\text { components, (setting; } \\
\text { indicated main factors } \\
\text { contributing to choice }\end{array}$ & $\begin{array}{l}\text { Describes } 3 / 5 \\
\text { components } \\
\text { (primary and } \\
\text { secondary }\end{array}$ & $\begin{array}{l}\text { Describes } 1 / 4 \\
\text { components } \\
\text { (details of } \\
\text { qualitative and }\end{array}$ & $\begin{array}{l}\text { Describes } 1 / 4 \\
\text { components } \\
\text { (characterizes relevant }\end{array}$ & $\begin{array}{l}\text { Describes } 2 / 5 \text { components } \\
\text { (presents data on changes } \\
\text { observed in measures } \\
\text { of patient outcome; }\end{array}$ & $\begin{array}{l}\text { Describes } 5 / 5 \\
\text { components } \\
\text { (summary; } \\
\text { relation to }\end{array}$ & $20 / 38$ \\
\hline
\end{tabular}


Table 2 Overview of reporting excellence according to the SQUIRE guidelines (Continued)

\begin{tabular}{|c|c|c|c|c|c|c|}
\hline $\begin{array}{l}\text { local problem; } \\
\text { intended aim; } \\
\text { and who, } \\
\text { what and why } \\
\text { of } \\
\text { intervention) }\end{array}$ & $\begin{array}{l}\text { of intervention; study } \\
\text { design for measuring } \\
\text { intervention; internal and } \\
\text { external validity) }\end{array}$ & $\begin{array}{l}\text { outcomes; validity } \\
\text { and reliability of } \\
\text { instruments; } \\
\text { explains methods } \\
\text { used to assure } \\
\text { data quality and } \\
\text { adequacy) }\end{array}$ & $\begin{array}{l}\text { quantitative } \\
\text { methods) }\end{array}$ & $\begin{array}{l}\text { elements of setting or } \\
\text { settings) }\end{array}$ & $\begin{array}{l}\text { presents evidence } \\
\text { regarding strength of } \\
\text { association between } \\
\text { intervention and changes) }\end{array}$ & $\begin{array}{l}\text { other evidence; } \\
\text { limitations; } \\
\text { interpretations; } \\
\text { conclusions) }\end{array}$ \\
\hline
\end{tabular}


[13-16, 18, 21-24, 26, 28, 29] or differences in patient outcomes $(\mathrm{N}=12)[13,16-24,28,29]$.

\section{Types of redesign interventions}

Table 3 summarizes the redesign interventions and study methods used. The objective of most studies was the implementation and evaluation of a specific redesign intervention. Improving quality of care was explicitly stated as an objective in seven studies [12, 15, 18, 20, 23, 25, 26]. Half of the redesign interventions implemented the approach known as lean thinking/Toyota production system $(\mathrm{N}=9)$ $[12,14,15,21,24-28]$. Two studies described the implementation of the concept of patient-centered medical home $[17,20]$, and three described more general forms of process redesign (structure redesign vs. process redesign [23], evidence-based redesign [18], nurse practitioner-led practice redesign [29]). Other interventions included a general process improvement project [16], appreciative inquiry [22], a hospitalist-led co-management neurosurgery service [13] and a continuum of care [19].

Fourteen studies were performed in the USA [12, 13, 15-17, 19-22, 25-29], two in Australia [14, 24], one in South Korea [23] and one in Scotland [18]. Most took place in a hospital setting $(\mathrm{N}=12)[13-16,19,21-24$, 27-29]; others were conducted in primary care $(\mathrm{N}=3)$ $[12,17,20]$, a specialized clinic $(\mathrm{N}=1)$ [18] or a laboratory $(\mathrm{N}=2)[25,26]$. Length of follow-up ranged from three [18] to 48 [27] months with a median of 12 months, though five studies did not mention its duration $[12,14,15,26,29]$. Patients were the most common unit of analysis $(\mathrm{N}=14)[13-15,17,18,20-25$, 27-29]. However, some studies reported on staff $(\mathrm{N}=2)$ $[12,21]$ or clinical notes $(\mathrm{N}=1)[12]$ while a few did not define the unit of analysis $(\mathrm{N}=3)[16,19,26]$. Mean sample size was $27,932.87(\mathrm{SD}=61,506.98)$, ranging from 49 [21] to 228,510 [20]. Thirteen studies used a before-and-after design $(\mathrm{N}=12)[12,14-16,20-24$, 27-29], while five used a controlled before-and-after design $[13,17,19,25,26]$.

In summary, half of the redesign interventions were characterized as 'lean thinking' and took place in a hospital setting. Length of follow-up and sample size diverged widely, and most studies used an uncontrolled before-and-after design to evaluate the effectiveness of the intervention.

\section{Effects of redesign on quality of care}

Table 4 summarizes the outcomes of the studies. All reported improvements as a result of process redesign, while three $[14,20,23]$ also found declines in quality. Significant improvements were mentioned in 15 studies $[13,14,16-21,23-28]$, mostly gains in effectiveness [16-21, 25, 27] and/or efficiency [14, 17-20, 23, 24, 26, 28 ]. Outcome measures showed great variance between studies. However, 'effectiveness' and 'efficiency' were discussed most (11 studies reported on both dimensions $[13,14,16-22,25,29])$. Changes in efficiency were demonstrated by 17 studies [12-25, 28, 29]. Efficiency was improved by decreasing hospitalization rates [17, 20], process times (including time to treatment) [14, 23, 24, $28]$, length of hospital stay $[19,23,29]$; by a shift in the writing of clinical notes [12], savings on (estimated) costs $[13,16,19,20,25,28]$, raising provider productivity $[21,22,26]$ and reducing process steps and variability $[15,18,24,25]$. Efficiency also deteriorated: an increase was shown in process time for a sub-category of patients $[14,23]$, in specialty care visits [20] and in specialty care costs [20].

Changes in effectiveness were demonstrated in 12 studies [13, 14, 16-22, 25, 27, 29]. These reported improvements in disease conditions [17, 20, 29] and adequate treatment usage $[16,22,29]$ as well as increases in discharged patients $[14,18]$ and diagnostic accuracy $[25,27]$.

Two studies [14, 15] found changes in timeliness as a result of process redesign, which reduced waiting time. Changes in patient-centeredness were demonstrated in three studies [13, 20, 22]: improvements in patient satisfaction or experiences [13, 20, 22]; higher scores on doctor-patient interaction; and better coordination of care [20]. Changes in patient safety were found in 11 studies [12, 14-16, 18, 19, 21, 24, 25, 27, 29]: increased physician identification [12]; improved documentation [12]; a decrease in complications $[14,16,19,21,29]$; fewer errors in routing patients to appointments [15]; fewer false-negative diagnoses [25, 27]; and an overall sense of improvement in patient safety [24].

None of the studies measured equity of care. Eight mentioned other outcomes unrelated to the six quality dimensions, such as changes in provider satisfaction $[12,22]$, staff perceptions of the implemented change $[13,14,18,21]$, changes in team morale [28], or changes in incident rates [18].

\section{Discussion}

The need to redesign healthcare processes in order to address deficits in quality of care and create more sustainable care processes is acknowledged worldwide $[2,3,5]$. The effects of process redesign have not been clearly described, however $[5,6]$. By synthesizing evidence from 18 studies in the international literature, this systematic review contributes to a better understanding of the influence of process redesign interventions on quality of care. It suggests that they have positive effects on certain aspects of quality. However, the full impact cannot be determined on the basis of the literature. Studies differed in the type 
Table 3 Overview of types of redesign interventions and methods used in included studies

\begin{tabular}{|c|c|c|c|c|c|c|}
\hline \multirow{2}{*}{$\begin{array}{l}\text { Reference (author } \\
\text { names, publication } \\
\text { year, country) }\end{array}$} & \multicolumn{2}{|l|}{ Intervention } & \multicolumn{4}{|l|}{ Methods } \\
\hline & Objectives & $\begin{array}{l}\text { Type of } \\
\text { intervention }\end{array}$ & Study design & $\begin{array}{l}\text { Unit of analysis } \\
\text { (project sample size), } \\
\text { study sample size }\end{array}$ & $\begin{array}{l}\text { Intervention } \\
\text { components }\end{array}$ & $\begin{array}{l}\text { Length of } \\
\text { follow-up }\end{array}$ \\
\hline $\begin{array}{l}1 . \\
\text { Pennell, et al. } \\
\text { (2005) USA }\end{array}$ & $\begin{array}{l}\text { To produce } \\
\text { substantiated practice } \\
\text { changes in glycemic } \\
\text { management and } \\
\text { improved outcomes } \\
\text { for coronary artery } \\
\text { bypass surgery } \\
\text { patients }\end{array}$ & $\begin{array}{l}\text { NP-led practice } \\
\text { redesign }\end{array}$ & $\begin{array}{l}\text { Before-and-after } \\
\text { study }\end{array}$ & $\begin{array}{l}\mathrm{N}=103 \text { (Before } \\
\text { group = 41; After } \\
\text { group =62). }\end{array}$ & $\begin{array}{l}\text { 1. } \\
\text { New cardiothoracic } \\
\text { team established, } \\
\text { including advanced } \\
\text { practice nurses; } 2 \text {. } \\
\text { 2. Implementation of } \\
\text { new tools and } \\
\text { guidelines }\end{array}$ & $\begin{array}{l}\text { Not } \\
\text { mentioned }\end{array}$ \\
\hline $\begin{array}{l}2 . \\
\text { King, Ben-Tovim, } \\
\text { Bassham (2006) } \\
\text { Australia }\end{array}$ & $\begin{array}{l}\text { Streamlining patient } \\
\text { care at the ED to } \\
\text { reduce overcrowding }\end{array}$ & Lean thinking & $\begin{array}{l}\text { Before-and-after } \\
\text { study }\end{array}$ & $\begin{array}{l}\text { Before: } N=49075 \\
\text { presentations to the } \\
\text { ED; After: } N=50337 \\
\text { presentations to the } \\
\text { ED. }\end{array}$ & $\begin{array}{l}1 . \\
\text { Process mapping } \\
\text { (incl. value stream } \\
\text { map);2. } \\
\text { Restructuring of } \\
\text { patient flow; } \\
\text { streamlining in } \\
\text { relation to predicted } \\
\text { outcome }\end{array}$ & 12 months \\
\hline $\begin{array}{l}\text { 3. } \\
\text { Raab, Andrew- } \\
\text { JaJA, Condel, } \\
\text { et al. (2006) USA }\end{array}$ & $\begin{array}{l}\text { Improving } \\
\text { Papanicolaou test } \\
\text { quality and reducing } \\
\text { medical errors by } \\
\text { using Toyota } \\
\text { production system } \\
\text { methods }\end{array}$ & $\begin{array}{l}\text { Toyota } \\
\text { production } \\
\text { system }\end{array}$ & $\begin{array}{l}\text { Non-concurrent } \\
\text { cohort study with } \\
\text { control-group and } \\
\text { comparison of retro- } \\
\text { spective consecutive } \\
\text { case data from previ- } \\
\text { ous year for same } \\
\text { time frame }\end{array}$ & $\begin{array}{l}\text { Women with ASC US } \\
\text { (atypical squamous } \\
\text { cells of undetermined } \\
\text { significance) } \\
\text { diagnosis }\end{array}$ & $\begin{array}{l}\text { 1. } \\
\text { Choosing a target for } \\
\text { improvement; } 2 \text {. } \\
\text { ProblemAnalysis;3. } \\
\text { Intervention design; } 4 \text {. } \\
\text { Pretest;5. } \\
\text { Implementation; } 6 . \\
\text { Evaluation }\end{array}$ & $\begin{array}{l}\text { Not } \\
\text { mentioned }\end{array}$ \\
\hline $\begin{array}{l}4 . \\
\text { Raab, et al. (2006) } \\
\text { USA }\end{array}$ & $\begin{array}{l}\text { Determine whether } \\
\text { the Toyota } \\
\text { production system } \\
\text { process redesign } \\
\text { resulted in diagnostic } \\
\text { error reduction for } \\
\text { patients who } \\
\text { underwent cytologic } \\
\text { evaluation of thyroid } \\
\text { nodules }\end{array}$ & $\begin{array}{l}\text { Toyota } \\
\text { production } \\
\text { system }\end{array}$ & $\begin{array}{l}\text { Longitudinal before- } \\
\text { and-after, non- } \\
\text { concurrent cohort } \\
\text { study }\end{array}$ & $\begin{array}{l}2,424 \text { patients with } \\
\text { thyroid gland nodule }\end{array}$ & $\begin{array}{l}1 . \\
\text { Development and use } \\
\text { of a standardized } \\
\text { diagnostic } \\
\text { terminology } \\
\text { scheme;2. } \\
\text { Expansion of an } \\
\text { immediate } \\
\text { interpretation service }\end{array}$ & $\begin{array}{l}\text { Not } \\
\text { mentioned }\end{array}$ \\
\hline $\begin{array}{l}5 . \\
\text { Shannon, et al. } \\
\text { (2006) USA }\end{array}$ & $\begin{array}{l}\text { Eliminating central } \\
\text { line-associated blood- } \\
\text { stream (CLAB) infec- } \\
\text { tions in ICUs by } \\
\text { employing the princi- } \\
\text { ples of Toyota pro- } \\
\text { duction system } \\
\text { adapted to health } \\
\text { care }\end{array}$ & $\begin{array}{l}\text { (Lean thinking) } \\
\text { Toyota } \\
\text { production } \\
\text { system }\end{array}$ & $\begin{array}{l}\text { Before-and-after } \\
\text { study }\end{array}$ & $\begin{array}{l}49 \text { patients with } \\
\text { CLAB admitted to } \\
\text { medical intensive } \\
\text { care unit } \\
\text { and coronary care } \\
\text { unit between July } \\
2002 \text { and June } 2003 \text {. } \\
10 \text { residents, } 10 \\
\text { fellows, } 8 \text { attending } \\
\text { physicians, } 16 \text { nurses, } \\
6 \text { nurse aides and } 5 \\
\text { personnel }\end{array}$ & $\begin{array}{l}\text { Real-time problem- } \\
\text { solving with help of } \\
\text { the Toyota produc- } \\
\text { tion system }\end{array}$ & 34 months \\
\hline $\begin{array}{l}6 . \\
\text { Kelly, Bryant, Cox, } \\
\text { et al. (2007) } \\
\text { Australia }\end{array}$ & $\begin{array}{l}\text { Analyze ED patient } \\
\text { flow processes using } \\
\text { task analysis and lean } \\
\text { thinking; re-engineer } \\
\text { these processes to } \\
\text { improve flow } \\
\text { through the ED for } \\
\text { all groups of patients }\end{array}$ & Lean thinking & $\begin{array}{l}\text { Before-and-after } \\
\text { study }\end{array}$ & $\begin{array}{l}31570 \text { patients } \\
\text { admitted to } \\
\text { emergency } \\
\text { department }\end{array}$ & $\begin{array}{l}\text { Choosing a target } \\
\text { for improvement; } \\
\text { problem analysis; } \\
\text { intervention design; } \\
\text { pretest; } \\
\text { implementation; and } \\
\text { evaluation }\end{array}$ & $\begin{array}{l}\text { Not } \\
\text { mentioned }\end{array}$ \\
\hline $\begin{array}{l}7 . \\
\text { Kim, et al. (2007) } \\
\text { USA }\end{array}$ & $\begin{array}{l}\text { Implement a lean } \\
\text { project to improve } \\
\text { patient care access }\end{array}$ & Lean thinking & $\begin{array}{l}\text { Before-and-after } \\
\text { study }\end{array}$ & $\begin{array}{l}1600 \text { patients in total/ } \\
\text { year, } 15 \% \text { have bone } \\
\text { or brain metastases }\end{array}$ & $\begin{array}{l}\text { Applied the principles } \\
\text { and tools of lean } \\
\text { thinking }\end{array}$ & $\begin{array}{l}\text { Not } \\
\text { mentioned }\end{array}$ \\
\hline
\end{tabular}


Table 3 Overview of types of redesign interventions and methods used in included studies (Continued)

\begin{tabular}{|c|c|c|c|c|c|c|}
\hline & $\begin{array}{l}\text { palliative radiation } \\
\text { therapy to patients } \\
\text { referred for bone or } \\
\text { brain metastases }\end{array}$ & & & & & \\
\hline $\begin{array}{l}8 . \\
\text { Raab, Grzybicki, } \\
\text { Condel, et al. } \\
\text { (2007) USA }\end{array}$ & $\begin{array}{l}\text { To measure the effect } \\
\text { of implementation of } \\
\text { a lean quality } \\
\text { improvement process } \\
\text { on the efficiency and } \\
\text { quality of a } \\
\text { histopathology lab } \\
\text { section }\end{array}$ & Lean thinking & $\begin{array}{l}\text { Non-concurrent } \\
\text { interventional cohort } \\
\text { study with control } \\
\text { group and pre-post } \\
\text { measurement }\end{array}$ & $\begin{array}{l}\text { One histopathology } \\
\text { section of anatomical } \\
\text { pathology laboratory }\end{array}$ & $\begin{array}{l}1 . \\
\text { Education of staff;2. } \\
\text { Determining current } \\
\text { condition;3. } \\
\text { Designing and } \\
\text { implementing } \\
\text { multiple (200) } \\
\text { interventions;4. } \\
\text { Sustaining the } \\
\text { "perfecting patient } \\
\text { care" learning line }\end{array}$ & $\begin{array}{l}\text { Not } \\
\text { mentioned }\end{array}$ \\
\hline $\begin{array}{l}9 . \\
\text { Shendel-Falik, } \\
\text { Feinson, Mohr } \\
\text { (2007) USA }\end{array}$ & $\begin{array}{l}\text { Develop and } \\
\text { implement a } \\
\text { standardized } \\
\text { approach to "hand- } \\
\text { off" communications, } \\
\text { including an } \\
\text { opportunity to ask } \\
\text { and respond to } \\
\text { questions }\end{array}$ & $\begin{array}{l}\text { Appreciative } \\
\text { inquiry }\end{array}$ & $\begin{array}{l}\text { Before-and-after } \\
\text { study }\end{array}$ & $\begin{array}{l}\text { Patients being } \\
\text { transitioned from the } \\
\text { ED to the telemetry } \\
\text { unit and the } \\
\text { associated care } \\
\text { providers involved in } \\
\text { the handoff }\end{array}$ & $\begin{array}{l}\text { A 5D cycle of } \\
\text { appreciative inquiry } \\
\text { (definition, discover, } \\
\text { dream, design, } \\
\text { destiny) with } 5 \\
\text { improvement } \\
\text { projects:1. } \\
\text { A welcome script;i2. } \\
\text { Safety assessments;3. } \\
\text { Standardized transfer } \\
\text { report;4. } \\
\text { Low-risk cardiac } \\
\text { transport protocol;5. } \\
\text { Interpersonal } \\
\text { relationships }\end{array}$ & 6 months \\
\hline $\begin{array}{l}10 . \\
\text { Wood, Brennan, } \\
\text { Chaudhry, et al. } \\
\text { (2008) USA }\end{array}$ & $\begin{array}{l}\text { To improve the } \\
\text { quality and safety of } \\
\text { patient care and to } \\
\text { improve the } \\
\text { efficiency and } \\
\text { satisfaction of all } \\
\text { team members, } \\
\text { including physicians }\end{array}$ & Lean thinking & $\begin{array}{l}\text { Before-and-after } \\
\text { study }\end{array}$ & $\begin{array}{l}1157 \text { consecutive } \\
\text { clinical notes before } \\
\text { and } 257 \text { clinical } \\
\text { notes after } \\
\text { implementation; } 137 \\
\text { physicians and } 12 \\
\text { allied health staff } \\
\text { members }\end{array}$ & $\begin{array}{l}\text { Standardized process } \\
\text { of patient care that } \\
\text { included collaborative } \\
\text { work between } \\
\text { physicians and } \\
\text { appropriately trained } \\
\text { clinical assistants; the } \\
\text { rooming process }\end{array}$ & $\begin{array}{l}\text { Not } \\
\text { mentioned }\end{array}$ \\
\hline $\begin{array}{l}11 . \\
\text { Reid, et al. (2009) } \\
\text { USA }\end{array}$ & $\begin{array}{l}1 . \\
\text { Maintain or enhance } \\
\text { patient care } \\
\text { experiences;2. } \\
\text { Reduce physician and } \\
\text { care team burnout;3. } \\
\text { Improve clinical } \\
\text { quality scores;4. } \\
\text { Reduce emergency, } \\
\text { specialty and } \\
\text { avoidable } \\
\text { hospitalization use } \\
\text { and costs }\end{array}$ & $\begin{array}{l}\text { Patient-centered } \\
\text { medical home }\end{array}$ & $\begin{array}{l}\text { Before-and-after } \\
\text { study }\end{array}$ & $\begin{array}{l}\text { One intervention } \\
\text { clinic and } 19 \text { control } \\
\text { clinics; } 8094 \text { patients } \\
\text { were included at the } \\
\text { PCMH clinic and } \\
228,510 \text { patients were } \\
\text { included at the } \\
\text { control clinics }\end{array}$ & $\begin{array}{l}1 . \\
\text { Structural changes;2. } \\
\text { Point-of-care process } \\
\text { changes; } 3 \text {. } \\
\text { Patient outreach } \\
\text { changes; } 4 \text {. } \\
\text { Management process } \\
\text { changes }\end{array}$ & 12 months \\
\hline $\begin{array}{l}12 . \\
\text { Auerbach, et al. } \\
\text { (2010) USA }\end{array}$ & $\begin{array}{l}\text { The co-management } \\
\text { neurosurgery service } \\
\text { (CNS) was imple- } \\
\text { mented in response } \\
\text { to changes in care-- } \\
\text { primarily reducing } \\
\text { availability of physi- } \\
\text { cians for ward patient- } \\
\text { s- which resulted } \\
\text { from resident duty } \\
\text { hour reductions }\end{array}$ & $\begin{array}{l}\text { Hospitalist-led } \\
\text { co-management } \\
\text { neurosurgery } \\
\text { service (CNS) }\end{array}$ & $\begin{array}{l}\text { Before-and-after } \\
\text { study with control } \\
\text { group }\end{array}$ & $\begin{array}{l}\text { A total of } 7596 \\
\text { patients were } \\
\text { admitted to the } \\
\text { neurosurgery service } \\
\text { during the study } \\
\text { period: } 4203(55.3 \%) \\
\text { before July } 1,2007 \text {, } \\
\text { and } 3393(44.7 \%) \\
\text { after CNS } \\
\text { implementation }\end{array}$ & $\begin{array}{l}\text { Co-management: } \\
\text { shared management } \\
\text { of surgical patients } \\
\text { between surgeons } \\
\text { and hospitalists }\end{array}$ & 18 months \\
\hline $\begin{array}{l}13 . \\
\text { Ravikumar, et al. } \\
\text { (2010) USA }\end{array}$ & $\begin{array}{l}\text { Reduce mortality by } \\
\text { enhancing continuity } \\
\text { and co-management } \\
\text { throughout hospital }\end{array}$ & $\begin{array}{l}\text { Continuum of } \\
\text { care }\end{array}$ & $\begin{array}{l}\text { Before-and-after } \\
\text { study with control } \\
\text { group }\end{array}$ & $\begin{array}{l}\text { Pilot study: one } \\
\text { intervention and one } \\
\text { control hospital. } \\
\text { Validation study: one }\end{array}$ & $\begin{array}{l}1 . \\
\text { Surgical Continuum } \\
\text { of Care (SCoC); } 2 \text {. }\end{array}$ & $\begin{array}{l}\text { Pilot study: } \\
3 \text { years; } \\
\text { Validation } \\
\text { study: }\end{array}$ \\
\hline
\end{tabular}


Table 3 Overview of types of redesign interventions and methods used in included studies (Continued)

\begin{tabular}{|c|c|c|c|c|c|c|}
\hline & $\begin{array}{l}\text { stay; minimize errors } \\
\text { at transition points; } \\
\text { increase throughput; } \\
\text { reduce length of stay }\end{array}$ & & & $\begin{array}{l}\text { hospital department } \\
\text { as intervention group } \\
\text { and the entire } \\
\text { hospital as control } \\
\text { cohortCoC study: one } \\
\text { hospital }\end{array}$ & $\begin{array}{l}\text { Continuum of Care } \\
(\mathrm{CoC})\end{array}$ & $\begin{array}{l}3 \text { years;CoC } \\
\text { study: } \\
6 \text { months }\end{array}$ \\
\hline $\begin{array}{l}14 . \\
\text { Hwang, Lee, Shin } \\
\text { (2011) South } \\
\text { Korea }\end{array}$ & $\begin{array}{l}\text { To shorten processing } \\
\text { time and improve } \\
\text { service quality }\end{array}$ & $\begin{array}{l}\text { Structure } \\
\text { redesign vs. } \\
\text { process redesign }\end{array}$ & Before-and-after study & $\begin{array}{l}\text { Two teaching } \\
\text { hospitals. At Guro } \\
\text { hospital (layout } \\
\text { redesign) the final } \\
\text { sample sizes were } 291 \\
\text { patients at baseline } \\
\text { and } 170 \text { patients at } \\
\text { follow-up. At Anam } \\
\text { hospital (critical path- } \\
\text { way implementation) } \\
\text { the final sample sizes } \\
\text { were } 273 \text { patients at } \\
\text { baseline and } 125 \text { pa- } \\
\text { tients at follow-up }\end{array}$ & $\begin{array}{l}1 . \\
\text { Structure-oriented } \\
\text { approach: } \\
\text { improvement of the } \\
\text { physical structure of } \\
\text { the ER operations by } \\
\text { remodeling the } \\
\text { hospital's layout;2. } \\
\text { Process-oriented } \\
\text { approach: } \\
\text { implementation of } \\
\text { critical pathways and } \\
\text { protocols }\end{array}$ & 12 months \\
\hline $\begin{array}{l}15 . \\
\text { Collar, et al. (2012) } \\
\text { USA }\end{array}$ & $\begin{array}{l}\text { To determine whether } \\
\text { systematic } \\
\text { implementation of } \\
\text { lean thinking in an } \\
\text { academic } \\
\text { otolaryngology } \\
\text { operating room } \\
\text { improves efficiency } \\
\text { and profitability and } \\
\text { preserves team morale } \\
\text { and educational } \\
\text { opportunities; all staff } \\
\text { working at one } \\
\text { surgeon's operating } \\
\text { room }\end{array}$ & Lean thinking & $\begin{array}{l}\text { Before-and-after } \\
\text { study (18-month } \\
\text { prospective quasi- } \\
\text { experimental study) }\end{array}$ & $\begin{array}{l}144 \text { cases were } \\
\text { included in the } \\
\text { baseline period and } \\
55 \text { cases in the } \\
\text { intervention period } \\
\text { (follow-up) }\end{array}$ & $\begin{array}{l}1 . \\
\text { Visualization of the } \\
\text { current state of the } \\
\text { perioperative work } \\
\text { process in the form } \\
\text { of a swim lane } \\
\text { diagram;2. } \\
\text { Identification of } \\
\text { waste;3. } \\
\text { Root cause analysis } \\
\text { for key waste items; } 4 \text {. } \\
\text { Creation of new } \\
\text { swim lanes and a } \\
\text { standard work matrix }\end{array}$ & 6 months \\
\hline $\begin{array}{l}16 . \\
\text { Krening, Rehling- } \\
\text { Anthony, Garko } \\
\text { (2012) USA }\end{array}$ & $\begin{array}{l}\text { To decrease risk } \\
\text { exposure in the use of } \\
\text { oxytocin } \\
\text { administration } \\
\text { hospitals of Centura } \\
\text { Health }\end{array}$ & $\begin{array}{l}\text { A process } \\
\text { improvement } \\
\text { project; } \\
\text { standardized } \\
\text { evidence-based } \\
\text { protocol and } \\
\text { processes across } \\
\text { the healthcare } \\
\text { system }\end{array}$ & $\begin{array}{l}\text { Before-and-after } \\
\text { study }\end{array}$ & $\begin{array}{l}\text { Nine hospitals of } \\
\text { Centura Health, } \\
\text { delivering obstetric } \\
\text { care }\end{array}$ & $\begin{array}{l}1 . \\
\text { A standardized } \\
\text { oxytocin mixture;2. } \\
\text { Low-dose } \\
\text { administration } \\
\text { guidelines;3. } \\
\text { Utilization of safety } \\
\text { checklists to assure } \\
\text { fetal and maternal } \\
\text { well-being before ini- } \\
\text { tiation of oxytocin } \\
\text { and increases in oxy- } \\
\text { tocin dosages;4. } \\
\text { A standardized order } \\
\text { set;5. } \\
\text { An educational hand- } \\
\text { out for pregnant } \\
\text { woman on oxytocin } \\
\text { usage }\end{array}$ & 12 months \\
\hline $\begin{array}{l}17 . \\
\text { Murray, Christen, } \\
\text { Marsh, et al. } \\
\text { (2012) Scotland }\end{array}$ & $\begin{array}{l}\text { Redesign of the new- } \\
\text { patient fracture clinic, } \\
\text { with the objective of: } \\
\text { improving patient } \\
\text { care, trainee educa- } \\
\text { tion, interprofessional } \\
\text { relations and clinic } \\
\text { efficiency }\end{array}$ & $\begin{array}{l}\text { Evidence-based } \\
\text { redesign }\end{array}$ & Not mentioned & $\begin{array}{l}301 \text { consecutive } \\
\text { patients attending the } \\
\text { new-patient fracture } \\
\text { clinic over a 3-week } \\
\text { period in the summer } \\
\text { of } 2010 \text {, compared to } \\
346 \text { consecutive pa- } \\
\text { tients during a 3-week } \\
\text { period exactly one } \\
\text { year previously. Ad- } \\
\text { equate data available } \\
\text { for } 240 \text { patients }\end{array}$ & $\begin{array}{l}1 . \\
\text { Investigate existing } \\
\text { conditions before } \\
\text { introducing the new } \\
\text { clinic model;2. } \\
\text { identify problems and } \\
\text { delineate potential } \\
\text { improvements;3. } \\
\text { Redesigned the new- } \\
\text { patient fracture } \\
\text { clinic;4. } \\
\text { Implemented }\end{array}$ & 3 months \\
\hline
\end{tabular}


Table 3 Overview of types of redesign interventions and methods used in included studies (Continued)

\begin{tabular}{|c|c|c|c|c|c|c|}
\hline & & & & $\begin{array}{l}(80 \%) \text { in } 2010 \text { and } \\
296 \text { patients }(86 \%) \text { in } \\
2009\end{array}$ & $\begin{array}{l}\text { change; } 5 . \\
\text { Documented } \\
\text { outcomes }\end{array}$ & \\
\hline $\begin{array}{l}18 . \\
\text { Liss, et al. (2013) } \\
\text { USA }\end{array}$ & $\begin{array}{l}\text { Providing patients } \\
\text { with a continuous } \\
\text { source of whole- } \\
\text { person primary care; } \\
\text { increasing patient ac- } \\
\text { cess and satisfaction } \\
\text { with care and redu- } \\
\text { cing total costs }\end{array}$ & $\begin{array}{l}\text { Patient-centered } \\
\text { medical home }\end{array}$ & $\begin{array}{l}\text { Controlled before- } \\
\text { and-after study }\end{array}$ & $\begin{array}{l}\text { One Group Health } \\
\text { clinic as intervention } \\
\text { site and } 19 \text { Group } \\
\text { Health Clinics as } \\
\text { controls. The final } \\
\text { study population } \\
\text { included } 37,930 \text { adults } \\
\text { with diabetes, } \\
\text { hypertension and/or } \\
\text { CHD, with } 1181 \\
\text { patients paneled to } \\
\text { the PCMH prototype } \\
\text { clinic and } 36,757 \\
\text { patients paneled to } \\
\text { other clinics }\end{array}$ & $\begin{array}{l}1 . \\
\text { Increased primary } \\
\text { care staffing;2. } \\
\text { Physicians paired in } \\
\text { dyads with medical } \\
\text { assistants;3. } \\
\text { Standard in-person } \\
\text { primary care office } \\
\text { visits lengthened to } \\
30 \text { min;4. } \\
\text { Virtual medicine con- } \\
\text { tacts;5. } \\
\text { Rerouting patients' } \\
\text { calls;6. } \\
\text { Creation of collabora- } \\
\text { tive care plans;7. } \\
\text { Provider outreach to } \\
\text { manage monitoring } \\
\text { tests }\end{array}$ & 21 months \\
\hline
\end{tabular}

of redesign implemented, study setting, methods used for evaluation, and outcome measures. All types of intervention seemed to improve outcomes in one or more respects. Nonetheless, it is not clear which type of redesign has the most potential in a particular setting. Efficiency, effectiveness and patient safety gains were best described in the included studies, while the effects on patient-centeredness, timeliness and equity of care received little attention.

Applying the SQUIRE guidelines demonstrated that overall the reporting was weak. Given the study designs, the results are subject to bias, as changes in the research settings might be responsible for the effects [30, 31]. In addition, changes in process might have been induced by background factors [31]. Longitudinal effects of redesign interventions were hardly evaluated, as follow-up varied from three to 48 months with a median of 12 months. The methodological problems of studies reporting on quality improvement interventions like process redesign are well known [6, 31-34]. Yet the methodology of the studies covered here was no better than in preceding studies. These weaknesses form potential threats to the internal and external validity of the findings. Unless a more uniform and robust evaluation of process redesign interventions is carried out, general conclusions cannot be drawn about their impact on quality of care.

To the best of our knowledge, this is the first systematic review of the effect of process redesign on quality of care, using broad definitions for both study setting and types of redesign. Elkhuizen et al. [6] performed a systematic review of the evidence of business process redesign in hospital settings until 2004. However, that review included studies combining multiple interventions, which made comparison impossible. Those authors concluded that studies were hard to find and lacked a clear and consistent research methodology. In that light, they recommended the development of reporting guidelines.

Specific redesign interventions have been reviewed recently. In one, Mazzocato et al. [35] reviewed the 'leanthinking' literature from a realist perspective, focusing on the mechanisms through which 'lean thinking' operated. The authors identified positive effects of lean implementation in all included studies and common contextual factors interacting with components of the lean interventions that triggered the change mechanisms. Here too, the use of unclear study designs or outcome measures is mentioned. The authors suspect publication bias, as only positive effects were being reported.

The impact of quality-improvement collaboratives was reviewed by Schouten et al. [36]. Although the outcomes were positive, the strength of evidence was limited by methodological constraints due to weak study designs, and the authors suspect positively biased findings. Implementation of the concept 'patient-centered medical home' was reviewed by Jackson et al. [37], who showed small positive effects on patient experience and care delivery. There too, the strength of evidence was moderate to low. Publications were hard to find, evidence was fragmented, and comparison between studies was hard if not impossible.

The findings of the present review are therefore in line with those of earlier studies on this topic in the sense that a broad perspective on redesign interventions and settings generates similar results. 
Table 4 Overview of outcomes of redesign interventions in included studies

\begin{tabular}{|c|c|c|c|c|c|c|c|}
\hline \multirow{2}{*}{$\begin{array}{l}\text { Study } \\
\text { reference } \\
\text { (author } \\
\text { names, } \\
\text { publication } \\
\text { year) }\end{array}$} & \multicolumn{6}{|l|}{ Quality of care } & \multirow[t]{2}{*}{ Other outcomes } \\
\hline & Effectiveness & Efficiency & Timeliness & $\begin{array}{l}\text { Patient- } \\
\text { centeredness }\end{array}$ & Safety & $\begin{array}{l}\text { Equity } \\
\text { of care }\end{array}$ & \\
\hline $\begin{array}{l}\text { 1. } \\
\text { Pennell, } \\
\text { et al. (2005) }\end{array}$ & $\begin{array}{l}\text { - } \\
\text { Improved basal } \\
\text { diabetes } \\
\text { medications being } \\
\text { ordered prior to } \\
\text { discontinuing the } \\
\text { IV insulin infusion } \\
(0 \% \rightarrow 76.9 \% \text { )- } \\
\text { Use of sliding scale } \\
\text { insulin increased in } \\
\text { undiagnosed } \\
\text { patients ( } 16 \% \rightarrow \\
21 \% \text { )- } \\
\text { Use of basal } \\
\text { medications while } \\
\text { on sliding scale } \\
\text { insulin improved } \\
\text { for diagnosed } \\
\text { patients ( } 56.3 \% \rightarrow \\
69 \% \text { )- } \\
\text { Increased number } \\
\text { of documented } \\
\text { blood glucose tests } \\
\text { ordered for } \\
\text { undiagnosed } \\
\text { patients (2.8/ } \\
\text { day } \rightarrow 4.3 / \text { day)- } \\
\text { Improved diabetic } \\
\text { patients' blood } \\
\text { glucose test values } \\
(88 \% \rightarrow 71 \% \\
\text { range } 140 \text { to } \\
299 \text { mm/dL) }\end{array}$ & $\begin{array}{l}\text { - } \\
\text { The Average } \\
\text { Length Of Stay } \\
\text { (ALOS) for the } \\
\text { overall population } \\
\text { was reduced by } \\
1.2 \text { days- } \\
\text { The ALOS for } \\
\text { diagnosed patients } \\
\text { increased by } \\
2.6 \text { days- } \\
\text { The ALOS for } \\
\text { undiagnosed } \\
\text { patients decreased } \\
\text { by } 4.6 \text { days- } \\
\text { The ALOS for } \\
\text { diagnosed patients } \\
\text { for the year was } \\
\text { shorter than for } \\
\text { undiagnosed } \\
\text { patients- } \\
\text { Patients with a } \\
\text { primary diagnosis } \\
\text { of coronary artery } \\
\text { bypass with } \\
\text { cardiac cath with } \\
\text { complications had } \\
\text { a significantly } \\
\text { longer ALOS at } \\
12.9 \text { days- } \\
\text { The ALOS of } \\
\text { undiagnosed } \\
\text { patients with } \\
\text { coronary bypass } \\
\text { with cardiac cath } \\
\text { dropped after } \\
\text { implementation }\end{array}$ & $\mathrm{n} / \mathrm{a}$ & $\mathrm{n} / \mathrm{a}$ & $\begin{array}{l}\text { - } \\
\text { Percentage of } \\
\text { undiagnosed } \\
\text { patients with } \\
\text { postoperative } \\
\text { infection } \\
\text { dropped } \\
(16 \% \rightarrow 9.1 \%) \text { - } \\
\text { Percentage of } \\
\text { diagnosed } \\
\text { patients with a } \\
\text { postoperative } \\
\text { infection } \\
\text { increased } \\
(0 \% \rightarrow 10 \%)- \\
\text { Diagnosed } \\
\text { patients had } \\
\text { fewer } \\
\text { postoperative } \\
\text { infections than } \\
\text { undiagnosed } \\
\text { patients (6.7\% } \\
\text { vs. } 12 \%)\end{array}$ & $\mathrm{n} / \mathrm{a}$ & $\mathrm{n} / \mathrm{a}$ \\
\hline $\begin{array}{l}2 . \\
\text { King, Ben- } \\
\text { Tovim, Bas- } \\
\text { sham } \\
(2006)\end{array}$ & $\mathrm{n} / \mathrm{a}$ & $\begin{array}{l}\text { - } \\
\text { Flattening of the } \\
\text { review times- } \\
\text { Marked reduction } \\
\text { in the variability of } \\
\text { time spent waiting } \\
\text { for review- } \\
\text { Time to initiation } \\
\text { of meaningful } \\
\text { treatment } \\
\text { significantly } \\
\text { decreased- } \\
\text { Time to see a } \\
\text { doctor decreased- } \\
\text { A slight increase in } \\
\text { overall compliance } \\
\text { to meeting triage } \\
\text { waiting times- } \\
\text { Percentage of all } \\
\text { patients attending } \\
\text { but not waiting to } \\
\text { be seen after initial } \\
\text { triaging fell } \\
\text { significantly- } \\
\text { Decrease in } \\
\text { patients presenting }\end{array}$ & $\mathrm{n} / \mathrm{a}$ & $\mathrm{n} / \mathrm{a}$ & $\begin{array}{l}\text { No incidents of } \\
\text { concerns } \\
\text { associated with } \\
\text { practice } \\
\text { change- } \\
\text { Overall sense of } \\
\text { a greater } \\
\text { degree of } \\
\text { patient safety, } \\
\text { and sense of } \\
\text { control among } \\
\text { staff }\end{array}$ & $\mathrm{n} / \mathrm{a}$ & $\mathrm{n} / \mathrm{a}$ \\
\hline
\end{tabular}


Table 4 Overview of outcomes of redesign interventions in included studies (Continued)

\begin{tabular}{|c|c|c|c|c|c|c|c|}
\hline & & $\begin{array}{l}\text { to the ED and } \\
\text { waiting for more } \\
\text { than } 8 \mathrm{~h} \text { before } \\
\text { being admitted or } \\
\text { discharged- } \\
\text { Significant } \\
\text { decrease in mean } \\
\text { time spent in the } \\
\text { ED- } \\
\text { Significant } \\
\text { decrease in time } \\
\text { spent in the ED of } \\
\text { patients being } \\
\text { admitted- } \\
\text { Significant } \\
\text { decrease in time } \\
\text { spent in the ED of } \\
\text { patients being } \\
\text { discharged- } \\
\text { Decrease of overall } \\
\text { time spent in the } \\
\text { department- } \\
\text { - Decrease of time } \\
\text { spent in the } \\
\text { department before } \\
\text { discharge }\end{array}$ & & & & & \\
\hline $\begin{array}{l}3 . \\
\text { Raab, } \\
\text { Andrew- } \\
\text { JaJA, Con- } \\
\text { del, et al. } \\
\text { (2006) }\end{array}$ & $\begin{array}{l}\text { Significant decrease } \\
\text { of Papanicolaou } \\
\text { tests lacking a } \\
\text { transformation } \\
\text { zone component } \\
(9.9 \% \rightarrow 4.7 \%)\end{array}$ & $\begin{array}{l}\text { - } \\
\text { Reduced number } \\
\text { of equivocal } \\
\text { Papanicolaou test } \\
\text { diagnoses } \\
\text { (7.8\% } \rightarrow 3.9 \% \text { \%)- } \\
\text { Decreased costs- } \\
\text { Less additional } \\
\text { testing (76\% } \% \\
29.4 \%)- \\
\text { Decreased } \\
\text { laboratory- } \\
\text { time and effort in } \\
\text { the screening of } \\
\text { slides }\end{array}$ & $\mathrm{n} / \mathrm{a}$ & $\mathrm{n} / \mathrm{a}$ & $\begin{array}{l}\text { - } \\
\text { More women } \\
\text { being } \\
\text { diagnosed with } \\
\text { appropriate } \\
\text { categories- } \\
\text { - Decrease of } \\
\text { error frequency } \\
\text { per correlating } \\
\text { cytologic- } \\
\text { histologic speci- } \\
\text { men pair } \\
(9.52 \% \rightarrow \\
7.84 \%)\end{array}$ & n/a & $\mathrm{n} / \mathrm{a}$ \\
\hline \multirow[t]{2}{*}{$\begin{array}{l}4 . \\
\text { Raab, et al. } \\
(2006)\end{array}$} & $\begin{array}{l}\text { - } \\
\text { Improvement:- } \\
\text { Significantly higher } \\
\text { diagnostic accuracy } \\
\text { (70.2\% } \% 90.6 \%) \text {-- } \\
\text { Decrease of Fine } \\
\text { Needle Aspiration } \\
\text { (FNA) }(1543 \rightarrow 1176 \\
\text { cases)- } \\
\text { Significant decrease } \\
\text { in repeated FNA } \\
\text { rate }(12.7 \% \rightarrow \\
7.7 \%) \text { - } \\
\text { Significant decrease } \\
\text { in non- } \\
\text { interpretable rate } \\
\text { for immediate in- } \\
\text { terpretation service } \\
(23.8 \% \rightarrow 7.8 \%)- \\
\text { Deteriorations:- } \\
\text { Significant increase } \\
\text { in non- } \\
\text { interpretable rate } \\
(5.8 \rightarrow 19.8 \%) \text { at } \\
\text { terminology } \\
\text { standardization }\end{array}$ & $\mathrm{n} / \mathrm{a}$ & $\mathrm{n} / \mathrm{a}$ & $\mathrm{n} / \mathrm{a}$ & $\begin{array}{l}- \\
\text { Significantly } \\
\text { fewer false- } \\
\text { negative diag- } \\
\text { noses }(4.8 \% \rightarrow \\
19.1 \%)- \\
\text { Significantly } \\
\text { fewer patients } \\
\text { had surgery } \\
(23.6 \% \rightarrow \\
19.9 \%)- \\
\text { Deteriorations:- } \\
- \text { No significant } \\
\text { increase in false- } \\
\text { positive rate } \\
(22.6 \rightarrow 26.3 \%)\end{array}$ & n/a & $\mathrm{n} / \mathrm{a}$ \\
\hline & & & $\mathrm{n} / \mathrm{a}$ & $\mathrm{n} / \mathrm{a}$ & & $\mathrm{n} / \mathrm{a}$ & \\
\hline
\end{tabular}


Table 4 Overview of outcomes of redesign interventions in included studies (Continued)

\begin{tabular}{|c|c|c|c|c|c|c|c|}
\hline $\begin{array}{l}5 . \\
\text { Shannon, } \\
\text { et al. (2006) }\end{array}$ & $\begin{array}{l}\text { - } \\
\text {-Significant increase } \\
\text { in line days } \\
(4,687 \text { days } \rightarrow \\
7,716 \text { days })\end{array}$ & $\begin{array}{l}\text { - } \\
\text { Increase in } \\
\text { admissions (11\%)- } \\
\text { Increased acuity- } \\
\text { Near doubling of } \\
\text { line use without } \\
\text { adding new staff } \\
\text { or more beds- } \\
\text { - Reduced need to } \\
\text { compensate for } \\
\text { ineffective } \\
\text { processes }\end{array}$ & & & $\begin{array}{l}\text { - } \\
\text { Reduced line } \\
\text { infection rates } \\
\text { after } \\
\text { intervention } \\
(10.5 / 1000 \rightarrow \\
0.39 / 1000 \text { line } \\
\text { days)- } \\
\text { - Significantly } \\
\text { reduced line } \\
\text { infection } \\
\text { associated } \\
\text { mortalities } \\
(51 \% \rightarrow 0 \%)\end{array}$ & & $\begin{array}{l}\text { More time to be } \\
\text { involved in direct } \\
\text { patient care- } \\
\text { - More time for } \\
\text { staff to solve } \\
\text { problems }\end{array}$ \\
\hline $\begin{array}{l}6 . \\
\text { Kelly, } \\
\text { Bryant, Cox, } \\
\text { et al. (2007) }\end{array}$ & $\begin{array}{l}\text { - } \\
\text { suscreased and } \\
\text { proportion of } \\
\text { discharged patients } \\
(92 \%)\end{array}$ & $\begin{array}{l}\text { - } \\
\text { Improvements:- } \\
\text { Significant } \\
\text { reduction of } \\
\text { overall total ED } \\
\text { department time } \\
\text { ( } 12 \text { min)- } \\
\text { Significant } \\
\text { reduction of total } \\
\text { ED time for triage } \\
\text { category } 4 \text { and } 5 \\
\text { patients ( } 14 \text { and } \\
18 \text { min } \\
\text { respectively)- } \\
\text { Deteriorations:- } \\
\left.\text { Significant }{ }^{*}\right) \\
\text { increase in total ED } \\
\text { time for category } \\
1,2 \text { and } 3 \text { patients } \\
\left(9,13 \text { and } 7^{*}\right. \\
\text { minutes } \\
\text { respectively) }\end{array}$ & $\begin{array}{l}\text { Significant reduction } \\
\text { inwaiting time, overall } \\
\text { and in triage } \\
\text { categories } 2-5(3,2,5 \text {, } \\
7 \text { and } 11 \text { min } \\
\text { respectively)Increased } \\
\text { bedrequests within } \\
\text { target time (73\%) }\end{array}$ & $\mathrm{n} / \mathrm{a}$ & $\begin{array}{l}\text { Episodes of } \\
\text { ambulance } \\
\text { bypass } \\
\text { significantly } \\
\text { decreased } \\
(120 \rightarrow 54)\end{array}$ & $\mathrm{n} / \mathrm{a}$ & $\begin{array}{l}\text { - } 90 \% \text { of staff } \\
\text { reported that they } \\
\text { believed the ED } \\
\text { ran better after the } \\
\text { change }\end{array}$ \\
\hline $\begin{array}{l}7 . \\
\text { Kim, et al. } \\
\text { (2007) }\end{array}$ & $\mathrm{n} / \mathrm{a}$ & $\begin{array}{l}\text { - } \\
\text { Reduction of } \\
\text { process steps (16) } \\
\text { to treatment- } \\
\text { Decrease of } \\
\text { variability }\end{array}$ & $\begin{array}{l}\text { Increase of } \\
\text { percentageof new } \\
\text { patients with brain or } \\
\text { bone metastases } \\
\text { receiving consultation, } \\
\text { simulation, and } \\
\text { treatment on the } \\
\text { same day ( } 43 \% \rightarrow \\
94 \%) \text { - } \\
\text { Process time } \\
\text { remained stable } \\
\text { (225 min) while wait } \\
\text { time decreased } \\
(1 \text { week } \rightarrow 1 \text { day) }\end{array}$ & $\mathrm{n} / \mathrm{a}$ & $\begin{array}{l}\text { Fewer process } \\
\text { errors in routing } \\
\text { patient to } \\
\text { appointment } \\
\text { times }\end{array}$ & $\mathrm{n} / \mathrm{a}$ & $\begin{array}{l}- \\
\mathrm{n} / \mathrm{a}\end{array}$ \\
\hline $\begin{array}{l}8 . \\
\text { Raab, } \\
\text { Grzybicki, } \\
\text { Condel, } \\
\text { et al. (2007) }\end{array}$ & $\mathrm{n} / \mathrm{a}$ & $\begin{array}{l}\text { - } \\
\text { Significantly } \\
\text { increased } \\
\text { productivity ( } 3439 \\
\text { to } 4047 \text { work } \\
\text { units/FTE)- } \\
\text { Decrease of } \\
\text { expenditure- } \\
\text { Decreased } \\
\text { specimen Turn } \\
\text { Around Time (TAT) } \\
\text { ( } 9.7 \mathrm{~h} \rightarrow 9.0 \mathrm{~h} \text { ) }\end{array}$ & $\mathrm{n} / \mathrm{a}$ & $\mathrm{n} / \mathrm{a}$ & $\mathrm{n} / \mathrm{a}$ & $\mathrm{n} / \mathrm{a}$ & $\mathrm{n} / \mathrm{a}$ \\
\hline $\begin{array}{l}9 . \\
\text { Shendel- } \\
\text { Falik, } \\
\text { Feinson, }\end{array}$ & $\begin{array}{l}\text { - } \\
\text { astritional } \\
\text { improvent by } 11 \% \text { - } \\
\text { Completion of skin }\end{array}$ & $\begin{array}{l}\text { - } \\
\text { Percentage of } \\
\text { telemetry patients } \\
\text { able to be } \\
\text { transported }\end{array}$ & $\mathrm{n} / \mathrm{a}$ & $\begin{array}{l}\text { - } \\
\text { Overall patient } \\
\text { satisfaction } \\
\text { improved on } \\
\text { nursing issues }\end{array}$ & $\mathrm{n} / \mathrm{a}$ & $\mathrm{n} / \mathrm{a}$ & $\begin{array}{l}\text { - Improved nurse } \\
\text { satisfaction and } \\
\text { teamwork }\end{array}$ \\
\hline
\end{tabular}


Table 4 Overview of outcomes of redesign interventions in included studies (Continued)

\begin{tabular}{|c|c|c|c|c|c|c|}
\hline $\begin{array}{l}\text { Mohr } \\
\text { (2007) }\end{array}$ & $\begin{array}{l}\text { assessment in the } \\
\text { ED improved by } \\
70 \%- \\
\text { - Compliance with } \\
\text { cardiac enzyme } \\
\text { regimen improved } \\
\text { by } 9.2 \%\end{array}$ & $\begin{array}{l}\text { without a cardiac } \\
\text { monitor increased } \\
\text { by } 60 \% \text { - } \\
67.5 \mathrm{~h} \text { of nursing } \\
\text { time per month } \\
\text { were saved. }\end{array}$ & $\begin{array}{l}\text { (10.2\%)- } \\
\text { Satisfaction with } \\
\text { personal issues } \\
\text { improved ( } 9 \%)- \\
\text { ED rating improved } \\
(23.3 \%)\end{array}$ & & & \\
\hline $\begin{array}{l}10 . \\
\text { Wood, } \\
\text { Brennan, } \\
\text { Chaudhry, } \\
\text { et al. (2008) }\end{array}$ & $\mathrm{n} / \mathrm{a}$ & $\begin{array}{l}\text { - } \\
\text { Shift from clinical } \\
\text { notes dictated by } \\
\text { physicians to } \\
\text { clinical notes } \\
\text { written by clinical } \\
\text { assistants- } \\
21 \% \text { of the note } \\
\text { was authored by } \\
\text { clinical assistants } \\
\text { and } 79 \% \text { by } \\
\text { physicians }\end{array}$ & $\mathrm{n} / \mathrm{a}$ & $\begin{array}{l}\text { - } \\
\text { ignificant } \\
\text { improvements:- } \\
\text { Increased } \\
\text { physician } \\
\text { identification } \\
\text { (from } 57 \% \text { to } \\
88 \% \text { )- } \\
\text { Increased } \\
\text { allergy } \\
\text { documentation } \\
\text { (from } 52 \% \text { to } \\
70 \% \text { )- } \\
\text { Increased } \\
\text { advance } \\
\text { directives } \\
\text { documentation } \\
\text { (from } 2 \% \text { to } \\
83 \% \text { )- } \\
\text { Improved } \\
\text { medication list } \\
\text { completeness } \\
\text { (from } 32 \% \text { to } \\
91 \% \text { ) }\end{array}$ & $\mathrm{n} / \mathrm{a}$ & $\begin{array}{l}\text { - } \\
\text { - Improved } \\
\text { physician } \\
\text { satisfaction }\end{array}$ \\
\hline $\begin{array}{l}11 . \\
\text { Reid, et al. } \\
\text { (2009) }\end{array}$ & $\begin{array}{l}\text { PCMH patients had } \\
\text { significantly better } \\
\text { performance on- } \\
\text { each of the } \\
\text { composite } \\
\text { measures } \\
\text { compared with } 19 \\
\text { other clinics at } \\
\text { baseline- } \\
\text { Significant } \\
\text { improvement of } \\
\text { composite quality } \\
\text { of care at the } \\
\text { PCMH compared to } \\
\text { baseline (4\%) and } \\
\text { control groups } \\
\text { (1.4\%) }\end{array}$ & $\begin{array}{l}\text { - } \\
\text { Improvements- } \\
\text { PCMH patients } \\
\text { received fewer in- } \\
\text { person primary } \\
\text { care visits (6\%)- } \\
\text { PCMH patients had } \\
\text { significantly fewer } \\
\text { ED visits ( } 29 \% \text { )- } \\
\text { PCMH patients had } \\
\text { significantly fewer } \\
\text { hospitalizations for } \\
\text { ambulatory care- } \\
\text { sensitive condi- } \\
\text { tions (11 \%)- } \\
\text { PCMH patients had } \\
\text { lower ED costs } \\
\text { (\$54 per patient } \\
\text { per year)- } \\
\text { Deteriorations:- } \\
\text { PCMH patients had } \\
\text { significantly more } \\
\text { specialty care visits } \\
\text { (8\%)- } \\
\text { PCMH patients had } \\
\text { higher primary } \\
\text { care costs per pa- } \\
\text { tient per year (\$16 } \\
\text { per patient per } \\
\text { year)- } \\
\text { PCMH patients had } \\
\text { higher specialty } \\
\text { care costs ( } \$ 37 \text { per } \\
\text { patient per year) }\end{array}$ & $\begin{array}{l}\text { - } \\
\text { PCMH patients } \\
\text { reported } \\
\text { significantly better } \\
\text { experience with } \\
\text { their care- } \\
\text { PCMH patients } \\
\text { reported } \\
\text { significantly higher } \\
\text { scores on quality of } \\
\text { doctor-patient inter- } \\
\text { actions, coordin- } \\
\text { ation of care, } \\
\text { patient activation/ } \\
\text { involvement and } \\
\text { goal setting/tailor- } \\
\text { ing- } \\
\text { Patients in the con- } \\
\text { trol groups reported } \\
\text { significantly higher } \\
\text { scores for patient } \\
\text { activation/involve- } \\
\text { ment and goal set- } \\
\text { ting/tailoring.- } \\
\text { Patients at the } \\
\text { PCMH clinic re- } \\
\text { ported significantly } \\
\text { higher scores on } \\
\text { quality of doctor- } \\
\text { patient interaction, } \\
\text { shared decision } \\
\text { making, coordin- } \\
\text { ation of care, ac- } \\
\text { cess, patient } \\
\text { activation/involve- } \\
\text { ment and goal set- } \\
\text { ting/tailoring }\end{array}$ & $\mathrm{n} / \mathrm{a}$ & $\mathrm{n} / \mathrm{a}$ & $\begin{array}{l}\text { - } \\
\text { Emotional } \\
\text { exhaustion among } \\
\text { physicians and } \\
\text { physician assistants } \\
\text { was reported } \\
\text { significantly less } \\
\text { frequently ( } 20 \% \text { ) at } \\
\text { the PCMH clinic }\end{array}$ \\
\hline
\end{tabular}


Table 4 Overview of outcomes of redesign interventions in included studies (Continued)

\begin{tabular}{|c|c|c|c|c|c|c|c|}
\hline $\begin{array}{l}12 . \\
\text { Auerbach, } \\
\text { et al. (2010) }\end{array}$ & $\begin{array}{l}\text { - } \\
\text { No significant } \\
\text { differences in } \\
\text { mortality rate- } \\
\text { No significant } \\
\text { differences in } \\
\text { readmission after } \\
30 \text { days }\end{array}$ & $\begin{array}{l}\text { - } \\
\text { Moderate decrease } \\
\text { in adjusted } \\
\text { hospital cost } \\
\text { equivalent to a } \\
\text { savings of } \$ 1439 \\
\text { per admission }\end{array}$ & $\mathrm{n} / \mathrm{a}$ & $\begin{array}{l}\text { - } \\
\text { Statistically } \\
\text { significant increases } \\
\text { in the odds for a } \\
\text { higher score in the } \\
\text { co-management } \\
\text { cohort for } 3 \text { ques- } \\
\text { tions: degree to } \\
\text { which staff } \\
\text { responded to con- } \\
\text { cerns; cheerfulness } \\
\text { of the hospital; and } \\
\text { degree to which } \\
\text { staff addressed pa- } \\
\text { tients' emotional } \\
\text { needs.- } \\
\text { - No significant dif- } \\
\text { ferences in overall } \\
\text { rating of the hos- } \\
\text { pital experience } \\
\text { and likelihood of } \\
\text { recommending the } \\
\text { hospital }\end{array}$ & $\mathrm{n} / \mathrm{a}$ & $\mathrm{n} / \mathrm{a}$ & $\begin{array}{l}\text { - } \\
\text { Non-nursing } \\
\text { professionals } \\
\text { support CNS; } \\
\text { significantly } \\
\text { improved attention } \\
\text { to medical issues } \\
\text { during } \\
\text { hospitalization and } \\
\text { at discharge- } \\
\text { - Nursing } \\
\text { perceptions of the } \\
\text { CNS's effect on } \\
\text { patient care were } \\
\text { uniformly positive, } \\
\text { with strongest } \\
\text { positive change } \\
\text { again being seen } \\
\text { on questions } \\
\text { regarding } \\
\text { treatment of } \\
\text { medical issues } \\
\text { during } \\
\text { hospitalization }\end{array}$ \\
\hline $\begin{array}{l}12 . \\
\text { Ravikumar, } \\
\text { et al. (2010) }\end{array}$ & $\begin{array}{l}\text { - Significant } \\
\text { improvement of } \\
\text { readmission rates }\end{array}$ & $\begin{array}{l}\text { - } \\
\text { Significant } \\
\text { reduction of total } \\
\text { hospital patient } \\
\text { days for patients } \\
\text { being discharged } \\
\text { from SICU to the } \\
\text { regular beds or to } \\
\text { PCU- } \\
\text { Net cost savings- } \\
\text { Decreased SICU } \\
\text { Length Of Stay } \\
\text { (LOS)- } \\
\text { Decreased PCU } \\
\text { LOS:- } \\
\text { Decreased total } \\
\text { hospital LOS SICU- } \\
\text { Decreased total } \\
\text { hospital LOS PCU- } \\
\text { Cost savings: } \\
\$ 851,511 \text { to } \\
\text { \$2,007,388 per } \\
\text { year.- } \\
\text { For DRG } 148, \\
\text { reduction of } \\
\text { variable cost was } \\
\text { \$452,000 per year }\end{array}$ & $\mathrm{n} / \mathrm{a}$ & $\mathrm{n} / \mathrm{a}$ & $\begin{array}{l}\text { - } \\
\text { Overall surgical } \\
\text { mortality } \\
\text { significantly } \\
\text { decreased, with } \\
\text { a corresponding } \\
\text { improvement in } \\
\text { mortality index } \\
\text { for surgical } \\
\text { DRGs }\end{array}$ & $\mathrm{n} / \mathrm{a}$ & $\mathrm{n} / \mathrm{a}$ \\
\hline $\begin{array}{l}13 . \\
\text { Hwang, } \\
\text { Lee, Shin } \\
(2011)\end{array}$ & $\mathrm{n} / \mathrm{a}$ & $\begin{array}{l}\text { - } \\
\text { Improvement } \\
\text { hospital layout } \\
\text { remodeling:- } \\
\text { Significant }(*) \\
\text { decrease of the } \\
\text { mean time for the } \\
\text { five processes: } \\
\text { registration } \\
\text { (7.78\%); CT/MRI } \\
\text { enrollment } \\
(8.75 \%) \text {; Complete } \\
\text { Blood Count (CBC) } \\
\text { sample collection } \\
(5.98 \%) \text {; } \\
\text { Prothrombin Time } \\
\text { (PT)/Partial }\end{array}$ & $\mathrm{n} / \mathrm{a}$ & n/a & $\mathrm{n} / \mathrm{a}$ & $\mathrm{n} / \mathrm{a}$ & $\mathrm{n} / \mathrm{a}$ \\
\hline
\end{tabular}


Table 4 Overview of outcomes of redesign interventions in included studies (Continued)

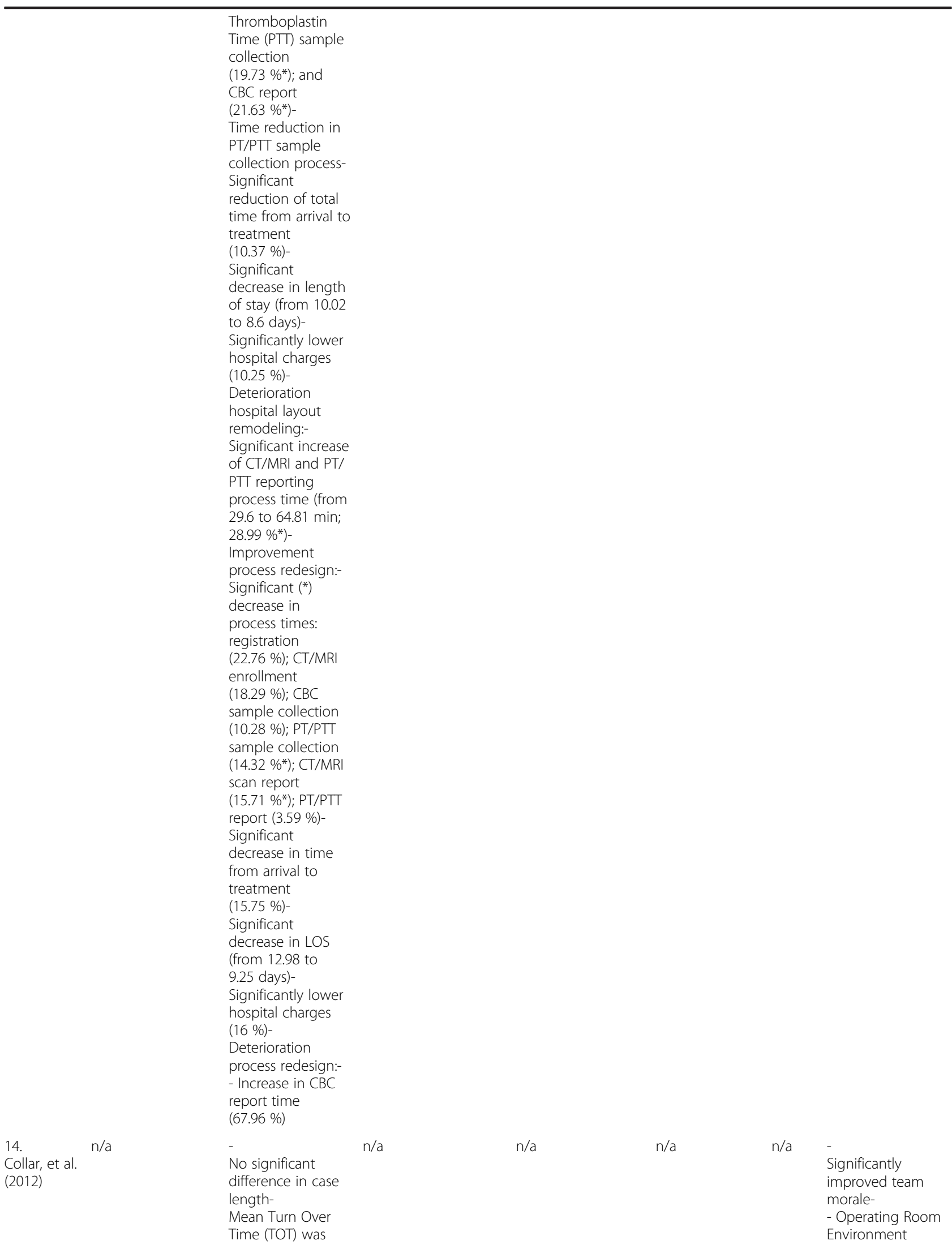


Table 4 Overview of outcomes of redesign interventions in included studies (Continued)

\begin{tabular}{|c|c|c|c|c|c|c|c|}
\hline & & $\begin{array}{l}\text { significantly } \\
\text { shortened- } \\
\text { Turn Around Time } \\
\text { (TAT) was } \\
\text { significantly } \\
\text { shortened- } \\
\text { Percentage of } \\
\text { TOTs of } 30 \text { min } \\
\text { increased- } \\
\text { Percentage of TATs } \\
\text { of } 60 \text { min } \\
\text { increased- } \\
\text { Approximately } \\
4,500 \text { min of } \\
\text { added capacity } \\
\text { yielded- } \\
\text { - Annual } \\
\text { opportunity } \\
\text { revenue for a } \\
\text { single OR used } \\
\text { twice weekly is } \\
\text { approximately } \\
\text { \$330,000 }\end{array}$ & & & & & $\begin{array}{l}\text { Measure did not } \\
\text { change } \\
\text { significantly }\end{array}$ \\
\hline $\begin{array}{l}15 . \\
\text { Krening, } \\
\text { Rehling- } \\
\text { Anthony, } \\
\text { Garko } \\
\text { (2012) }\end{array}$ & $\begin{array}{l}\text { - } \\
\text { Decrease in } \\
\text { average length of } \\
\text { labor on oxytocin } \\
\text { for both } \\
\text { primigravidas } \\
(10 \mathrm{~h} \rightarrow 9.5 \mathrm{~h}) \text { and } \\
\text { multigravidas } \\
(8 \mathrm{~h} \rightarrow 6.5 \mathrm{~h}) \text {-- } \\
\text { Significant decrease } \\
\text { in hours receiving } \\
\text { oxytocin for both } \\
\text { primigravidas } \\
(9.9 \mathrm{~h} \rightarrow 8.78 \mathrm{~h}) \\
\text { and multigravidas } \\
(7.8 \mathrm{~h} \rightarrow 6.22 \mathrm{~h} \text { )- } \\
\text { Decrease in primary } \\
\text { cesarean rate } \\
(61 \% \rightarrow 56 \%)\end{array}$ & $\begin{array}{l}\text { - } \\
\text { A theoretical } \\
\text { saving of at least } \\
\$ 173,000 \text { per year } \\
\text { if volume remains } \\
\text { constant, caused } \\
\text { by reduced labor } \\
\text { length- } \\
\text { A theoretical } \\
\text { saving of } \\
\text { approximately } \\
\$ 286,000 \text { per year, } \\
\text { caused by reduced } \\
\text { primary cesareans }\end{array}$ & $\mathrm{n} / \mathrm{a}$ & $\mathrm{n} / \mathrm{a}$ & $\begin{array}{l}\text { - } \\
\text { Significant } \\
\text { decrease in } \\
\text { overall } \\
\text { incidence of } \\
\text { tachysystole } \\
(54 \% \rightarrow 20 \%)\end{array}$ & n/a & $\mathrm{n} / \mathrm{a}$ \\
\hline $\begin{array}{l}16 . \\
\text { Murray, } \\
\text { Christen, } \\
\text { Marsh, et al. } \\
\text { (2012) }\end{array}$ & $\begin{array}{l}\text { - } \\
\text { Significant decrease } \\
\text { in overall 'return } \\
\text { rates' (162 } \rightarrow 97 \\
\text { patients)- } \\
\text { Discharge rate } \\
\text { improved ( } 22 \% \rightarrow \\
25 \% \text { ) }\end{array}$ & $\begin{array}{l}\text { - } \\
\text { Significant } \\
\text { decrease in } \\
\text { proportion of } \\
\text { patients requiring } \\
\text { additional physical } \\
\text { review by a } \\
\text { consultant ( } 89 \rightarrow \\
22 \text { patients)- } \\
\text { Significant } \\
\text { improvement in } \\
\text { utilization of the } \\
\text { nurse-led fracture } \\
\text { clinic (38 } \rightarrow 55 \\
\text { referrals) }\end{array}$ & $\mathrm{n} / \mathrm{a}$ & $\mathrm{n} / \mathrm{a}$ & $\begin{array}{l}- \\
\text { Significant } \\
\text { increase in } \\
\text { proportion of } \\
\text { cases receiving } \\
\text { primary } \\
\text { consultant input } \\
(98 \rightarrow 202 \\
\text { patients })\end{array}$ & $\mathrm{n} / \mathrm{a}$ & $\begin{array}{l}\text { - } \\
\text { Significant } \\
\text { improvements in } \\
\text { median scores of } \\
\text { staff perception of } \\
\text { education, } \\
\text { provision of senior } \\
\text { support, morale } \\
\text { and overall } \\
\text { perception of } \\
\text { patient care.- } \\
\text { ER staff said the } \\
\text { new style clinic } \\
\text { was educational, } \\
\text { practice-changing } \\
\text { and improved } \\
\text { interdisciplinary re- } \\
\text { lations- } \\
\text { - Reduction of offi- } \\
\text { cial incidence rates } \\
\text { IR1 reports }\end{array}$ \\
\hline $\begin{array}{l}17 . \\
\text { Liss, et al. } \\
(2013)\end{array}$ & $\begin{array}{l}\text { - } \\
\text { Significantly } \\
\text { improved disease } \\
\text { conditions for } \\
\text { patients with }\end{array}$ & $\begin{array}{l}\text { - } \\
\text { Significant } \\
\text { decrease }(23 \%) \text { in } \\
\text { ambulatory care } \\
\text { sensitive }\end{array}$ & $\mathrm{n} / \mathrm{a}$ & $\mathrm{n} / \mathrm{a}$ & $\mathrm{n} / \mathrm{a}$ & $\mathrm{n} / \mathrm{a}$ & $\mathrm{n} / \mathrm{a}$ \\
\hline
\end{tabular}


Table 4 Overview of outcomes of redesign interventions in included studies (Continued)

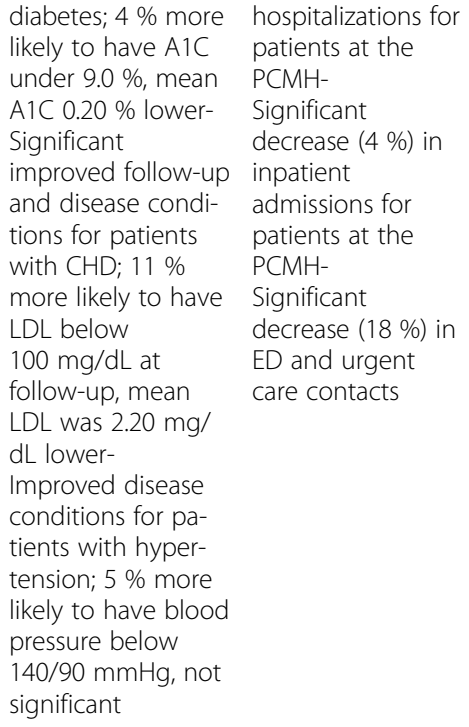

\section{Limitations}

Even though a systematic approach guided this review, the findings might be subject to some bias, which should be kept in mind when interpreting them.

First, publication bias might be present: most of the studies report on positive findings, and there is a general tendency in scientific literature to over-represent positive results [38]. As previous research on this topic also raised concerns about publication bias, this issue is pertinent to this review too. It is unlikely that using predefined redesign concepts would have addressed this problem, as publication bias was a concern in reviews that did use such concepts [35], underlining the need to report all outcomes of redesign in healthcare.

Second, limiting the scope by only including studies that used before-and-after measurement might have led to some selection bias. Nonetheless, limiting the search strategy did ensure a solid basis for comparison of the effects of the redesign interventions.

Third, since the terminology used to describe the interventions varies greatly, we could have missed some relevant studies. We circumvented this problem by searching multiple databases with database-specific headings like $\mathrm{MeSH}$ terms and amplifying the strategy by searching with free-text words.

Fourth, the SQUIRE guidelines might not be the only instrument for assessing excellence in reporting. Although they were specifically developed to assess reporting excellence for this type of studies, the checklist does not provide a value judgment on the methodology (or strength of evidence) of the studies [11]. Nonetheless, by covering methodological components, the SQUIRE checklist gives a sense of the methodological strengths of a study.
Finally, using the IoM dimensions of quality of care might have made it difficult to compare findings across studies. Since the IoM does not specify which outcome measures belong to the six dimensions, there is room for interpretation. Even though this might have influenced the presentation of findings in this review, using the IoM dimensions facilitated classification of the outcomes, thereby revealing gaps in the research literature.

\section{Conclusion}

Scientific evidence supporting process redesign in healthcare is limited and inconsistent. Outcome measures for the effect of redesign interventions vary across studies to the extent that it is impossible to draw conclusions about the impact on overall quality of care, or even on some of its dimensions. The findings of this systematic review suggest that the evaluation of process redesign interventions should be improved to reveal their full effect. It should meet the basic standards for reporting (SQUIRE guidelines) and apply more robust research designs. The influence of process redesign on patient-centered care, equity of care and timeliness warrants further research, applying outcome measures that capture the full scope of quality of care. Current research tends to ignore the long-term effects of process redesigns. Robust evaluations of their implementation should also identify the mechanisms through which effects were realized. This would help researchers and policymakers determine the value of specific interventions and offer an overview of improvement efforts that is less fragmented. 


\section{Appendix 1}

Table 5 Search terms used

PubMed: Medical Subject Heading (MesH) terms

(((("Organizational Innovation"[Mesh] OR "hospital restructuring"[MeSH Terms] OR "Health Care Reform"[Mesh]) AND ("Delivery of Health Care"[Mesh] OR "Health Care Sector"[Mesh])) AND ("Institutional Practice"[Mesh] OR "Clinical Protocols"[Mesh] OR "Physician's Practice Patterns"[Mesh] OR "Nurse's Practice Patterns"[Mesh])) AND ("Quality Improvement"[Mesh] OR "Quality of Health Care"[Mesh] OR "Health Care Quality, Access, and Evaluation"[Mesh] OR "Efficiency, Organizational" [Mesh] OR "total quality management" [Mesh] OR "patient safety" [Mesh] OR "patient-centered care" [Mesh]))

PubMed: Free-text words

((redesign*[Title/Abstract]OR restructur*[Title/Abstract] OR "process improvement" Title/Abstract]) AND healthcare [Title/Abstract](AND routin* [Title/Abstract] OR process* [Title/Abstract]) AND ("quality of care" [Title/Abstract] OR "efficien" * [Title/Abstract] OR "safe*" [Title/ Abstract] OR "timel*" [Title/Abstract] OR "effective*" [Title/Abstract] OR "patient-centered" [Title/Abstract] OR "equitable" [ittle/Abstract])

\section{CINAHL: CINAHL Headings terms}

((MH "Work Redesign") OR (MH "Health Care Reform") OR (MH "Organizational Change") OR (MH "Organizational Restructuring")) AND (MH "Health Care Delivery") AND ((MH "Medical Practice") OR (MH "Advanced Nursing Practice") OR (MH "Professional Practice, ResearchBased") OR (MH "Professional Practice, Theory-Based") OR (MH "Nursing Practice") OR (MH "Professional Practice, Evidence-Based") OR (MH "Nursing Practice, Theory-Based") OR (MH "Nursing Practice, Research-Based") OR (MH "Nursing Practice, Evidence-Based") OR (MH "Medical Practice, Research-Based") OR (MH "Medical Practice, Evidence-Based") OR (MH "Nursing Care") OR (MH "Practice Patterns")) AND ((MH "Quality of Health Care") OR (MH "Quality Management, Organizational") OR (MH "Quality Assessment") OR (MH "Quality Improvement") OR (MH "Quality Assurance") OR (MH "Quality of Nursing Care") OR (MH "Patient Safety") OR (MH "Organizational Efficiency") OR (MH "Patient Centered Care"))

\section{CINAHL: Free-text words}

(redesign* OR restructure* OR "process improvement") AND healthcare AND (routin* OR proces*) AND ("quality of care" OR efficiency OR safe* OR timel* OR effectiveness OR "patient-centered" OR equitable)

Web of Science: Free-text words

(redesign* OR restructure* OR "process improvement") AND healthcare AND (routin* OR proces*) AND ("quality of care" OR efficiency OR safe* OR timel* OR effectiveness OR "patient-centered" OR equitable)

Business Premier Source: Thesaurus terms

(((((DE "REENGINEERING (Management)") OR (DE "PROCESS optimization")) OR (DE "ORGANIZATIONAL change")) AND (DE "MEDICAL care")) AND (DE "ORGANIZATIONAL effectiveness"))

Business Premier Source: free-text words (redesign* OR restructure* OR "process improvement") AND healthcare AND (routin* OR proces*) AND ("quality of care" OR efficiency OR safe* OR timel* OR effectiveness OR "patient-centered" OR equitable)

\section{Competing interests}

The authors declare that they have no competing interest.

\section{Authors' contributions}

All authors have contributed to the design, analysis or interpretation of the systematic review, either being the design of the search strategy (all authors) or the design, analysis and interpretation of data (JVLZ, AE, KG). Each author helped draft the manuscript and all authors have seen and agreed with the final contents of the article.

\section{Acknowledgements}

The authors would like to thank Nancy Smyth van Weesep for checking the manuscript for the correct use of the English language. This systematic review was not funded, and no funders had input into design or conduct of the review. JVLZ, AE, AVR and DR were funded by Maastricht University and BK was funded by the Maastricht University Medical Center.

\section{Author details}

${ }^{1}$ Department of Health Services Research, School for Public Health and Primary Care (CAPHRI), Maastricht University, Maastricht, The Netherlands. ${ }^{2}$ Faculty of Health, Medicine and Life Sciences, Maastricht University, Maastricht, The Netherlands. ${ }^{3}$ Saw Swee Hock School of Public Health, National University of Singapore, Singapore, Singapore. ${ }^{4}$ Scientific Center of Care and Welfare (Tranzo), Tilburg University, Tilburg, The Netherlands. ${ }^{5}$ Department of Family Medicine, Free University of Brussels, Brussels, Belgium. ${ }^{6}$ Department of Otorhinolaryngology, Head and Neck Surgery, Maastricht University Medical Center, Maastricht, The Netherlands.

Received: 17 March 2015 Accepted: 12 January 2016

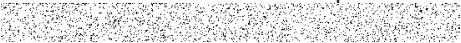

\section{References}

1. Hofmarcher MM, Oxley H, Rusticelli E. Improved Health System Performance Through Better Care Coordination. OECD Health Working Paper No 30. Paris: The Organisation for Economic Co-operation and Development; 2007.

2. Institute of Medicine. Crossing the Quality Chasm: A New Health System for the 21st Century. Washington, DC: National Academies Press; 2001.

3. OECD. Health at a Glance: Europe 2012. Paris: The Organisation for Economic Co-operation and Development; 2012.

4. Fuchs VR, Emanuel EJ. Health care reform: Why? What? When? Health Aff. 2005:24(6):1399-414.

5. Institute of Medicine. Performance Measurement: Accelerating Improvement. Washington, D.C.: Institute of Medicine; 2006.

6. Elkhuizen SG, Limburg M, Bakker PJ, Klazinga NS. Evidence-based reengineering: re-engineering the evidence. A systematic review of the literature on business process redesign (BPR) in hospital care. Int J Health Care Qual Assur. 2006:19(6-7):477-99.

7. Vest JR, Gamm LD. A critical review of the research literature on Six sigma, lean and StuderGroup's hardwiring excellence in the united states: the need to demonstrate and communicate the effectiveness of transformation strategies in healthcare. Impl Sc. 2009;4:35.

8. Harmon P, Business Process Change. A manager's guide to improving redesigning and automating processes. San Francisco, CA: Morgan Kaufmann Publishers; 2003.

9. Donabedian A. An introduction to Quality Assurance. In: Bashshur R, editor. Health Care. Oxford: University Press; 2003.

10. Moher D, Liberati A, Tetzlaff J, Altman DG. Preferred reporting items for systematic reviews and meta-analyses: the PRISMA statement. BMJ. 2009;339:b2535

11. Ogrinc G, Mooney SE, Estrada C, Foster T, Goldmann D, Hall LW, et al. The SQUIRE [Standards for Quality Improvement Reporting Excellence] guidelines for quality improvement reporting: explanation and elaboration. Qual Saf Health Care. 2008;17 Suppl 1:113-32.

12. Wood DL, Brennan MD, Chaudhry R, Chihak AA, Feyereisn WL, Woychick NL, et al. Standardized care processes to improve quality and safety of patient care in a large academic practice: the Plummer Project of the Department of Medicine, Mayo Clinic. Health Serv Manage Res. 2008;21(4):276-80.

13. Auerbach $A D$, Wachter RM, Cheng HQ, Maselli J, McDermott M, Vittinghoff

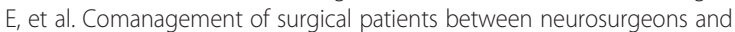
hospitalists. Arch Int Med. 2010;13;170(22):2004-10.

14. Kelly AM, Bryant M, Cox L, Jolley D. Improving emergency department efficiency by patient streaming to outcomes-based teams. Aust Health Rev. 2007;31(1):16-21.

15. Kim CS, Hayman JA, Billi, JE, Lash K, Lawrence TS. The application of lean thinking to the care of patients with bone and brain metastasis with radiation therapy. J Oncol Pract. 2007:3(4):189-93.

16. Krening CF, Rehling-Anthony K, Garko C. Oxytocin administration: the transition to a safer model of care. J Perinat Neonat Nur. 2012:26(1):15-24.

17. Liss DT, Fishman PA, Rutter CM, Grembowski D, Ross TR, Johnson EA, et al. Outcomes among chronically III adults in a medical home prototype. Am J Manag Care. 2013;19(10):E348-+. 
18. Murray O, Christen K, Marsh A, Bayer J. Fracture clinic redesign: improving standards in patient care and interprofessional education. Swiss Med Wkly. 2012;142:w13630.

19. Ravikumar TS, Sharma C, Marini C, Steele GD Jr, Ritter G, Barrera R, et al. A validated value-based model to improve hospital-wide perioperative outcomes: adaptability to combined medical/surgical inpatient cohorts. Ann Surg. 2010;252(3):486-96. discussion 96-8.

20. Reid RJ, Fishman PA, Yu O, Ross TR, Tufano JT, Soman MP, et al. Patientcentered medical home demonstration: a prospective, quasi-experimental, before and after evaluation. Am J Manag Care. 2009;15(9):E71-87.

21. Shannon RP, Frndak D, Grunden N, Lloyd JC, Herbert C, Patel B, et al. Using real-time problem solving to eliminate central line infections. Jt Comm J Qual Patient Saf. 2006:32(9):479-87.

22. Shendel-Falik N, Feinson M, Mohr BJ. Enhancing patient safety - Improving the patient handoff process through appreciative inquiry. J Nurs Admin. 2007;37(2):95-104

23. Hwang TG, Lee $Y$, Shin $H$. Structure-oriented versus process-oriented approach to enhance efficiency for emergency room operations: what lessons Can We learn? J Healthc Manag. 2011;56(4):255-67.

24. King DL, Ben-Tovim DI, Bassham J. Redesigning emergency department patient flows: application of lean thinking to health care. Emerg Med Australas. 2006;18(4):391-7.

25. Raab SS, Andrew-Jaja C, Condel JL, Dabbs DJ. Improving Papanicolaou test quality and reducing medical errors by using Toyota production system methods. Am J Obstet Gynecol. 2006;194(1):57-64.

26. Raab SS, Grzybicki DM, Condel JL, Stewart WR, Turcsanyi BD, Mahood LK, et al. Effect of Lean method implementation in the histopathology section of an anatomical pathology laboratory. J Clin Pathol. 2008;61(11):1193-9.

27. Raab SS, Grzybicki DM, Sudilovsky D, Balassanian R, Janosky JE, Vrbin CM Effectiveness of Toyota process redesign in reducing thyroid gland fineneedle aspiration error. Am J Clin Pathol. 2006;126(4):585-92.

28. Collar RM, Shuman AG, Feiner S, McGonegal AK, Heidel N, Duck M, et al. Lean management in academic surgery. J Am Coll Surg. 2012;214(6):928-36.

29. Pennell L, Smith-Snyder CM, Hudson LR, Hamar GB, Westerfield J. Practice changes in glycemic management and outcomes in coronary artery bypass surgery patients. J Cardiovasc Nurs. 2005;20(1):26-34.

30. Dimitrov DM, Rumrill Jr PD. Pretest-posttest designs and measurement of change. Work. 2003;20(2):159-65.

31. Shojania KG, Grimshaw JM. Evidence-based quality improvement: the state of the science. Health Aff. 2005;24(1):138-50.

32. Hulscher ME, Laurant MG, Grol RP. Process evaluation on quality improvement interventions. Qual Saf Health Care. 2003;12(1):40-6.

33. Nolte E, Conklin A, Adams J, Brunn M, Cadier B, Chevreul K, et al. Evaluating chronic disease management. Recommendations for funders and users. Santa Monica, CA: RAND Corporation; 2012.

34. Ovretveit J, Gustafson D. Evaluation of quality improvement programmes. Qual Saf Health Care. 2002;11(3):270-5.

35. Mazzocato P, Savage C, Brommels M, Aronsson H, Thor J. Lean thinking in healthcare: a realist review of the literature. Qual Saf Health Care. 2010;19(5):376-82.

36. Schouten LM, Hulscher ME, van Everdingen JJ, Huijsman R. Grol RP: evidence for the impact of quality improvement collaboratives: systematic review. BMJ. 2008;336(7659):1491-4.

37. Jackson GL, Powers BJ, Chatterjee R, Bettger JP, Kemper AR, Hasselblad V, et al. Improving patient care. The patient centered medical home. A systematic review. Ann Intern Med. 2013;158(3):169-78.

38. Chalmers I, Glasziou P, Godlee F. All trials must be registered and the results published. BMJ. 2013;346:f105.

\section{Submit your next manuscript to BioMed Central and we will help you at every step:}

- We accept pre-submission inquiries

- Our selector tool helps you to find the most relevant journal

- We provide round the clock customer support

- Convenient online submission

- Thorough peer review

- Inclusion in PubMed and all major indexing services

- Maximum visibility for your research

Submit your manuscript at www.biomedcentral.com/submit 